\title{
Physiology and pathology of calcium signaling in the brain
}

\author{
Elisa Mitiko Kawamoto ${ }^{\dagger}$, Carmen Vivar $^{\dagger}$ and Simonetta Camandola* \\ Laboratory of Neurosciences, National Institute on Aging, Intramural Research Program, Baltimore, MD, USA
}

Edited by:

Amalia M. Dolga, Philipps-Universität Marburg, Germany

Reviewed by:

Ashok Kumar, University of Florida, USA

Jason B. Wu, Cedars-Sinai Medical Center, USA

\section{${ }^{*}$ Correspondence:}

Simonetta Camandola, Laboratory of Neurosciences, National Institute on Aging, Intramural Research Program, 251 Bayview Blvd, Baltimore, MD 21224, USA.

e-mail: camandolasi@mail.nih.gov

${ }^{\dagger}$ Elisa Mitiko Kawamoto and Carmen Vivar have contributed equally to this work.
Calcium $\left(\mathrm{Ca}^{2+}\right)$ plays fundamental and diversified roles in neuronal plasticity. As second messenger of many signaling pathways, $\mathrm{Ca}^{2+}$ as been shown to regulate neuronal gene expression, energy production, membrane excitability, synaptogenesis, synaptic transmission, and other processes underlying learning and memory and cell survival. The flexibility of $\mathrm{Ca}^{2+}$ signaling is achieved by modifying cytosolic $\mathrm{Ca}^{2+}$ concentrations via regulated opening of plasma membrane and subcellular $\mathrm{Ca}^{2+}$ sensitive channels. The spatiotemporal patterns of intracellular $\mathrm{Ca}^{2+}$ signals, and the ultimate cellular biological outcome, are also dependent upon termination mechanism, such as $\mathrm{Ca}^{2+}$ buffering, extracellular extrusion, and intra-organelle sequestration. Because of the central role played by $\mathrm{Ca}^{2+}$ in neuronal physiology, it is not surprising that even modest impairments of $\mathrm{Ca}^{2+}$ homeostasis result in profound functional alterations. Despite their heterogeneous etiology neurodegenerative disorders, as well as the healthy aging process, are all characterized by disruption of $\mathrm{Ca}^{2+}$ homeostasis and signaling. In this review we provide an overview of the main types of neuronal $\mathrm{Ca}^{2+}$ channels and their role in neuronal plasticity. We will also discuss the participation of $\mathrm{Ca}^{2+}$ signaling in neuronal aging and degeneration.

Keywords: calcium channels, synaptic plasticity

\section{INTRODUCTION}

Calcium $\left(\mathrm{Ca}^{2+}\right)$ plays fundamental and diversified roles in neuronal physiology. For example, by regulating the release of neurotransmitters from the presynaptic terminals it influences both long-term potentiation (LTP; Grover and Teyler, 1990; Impey et al., 1996) and long-term depression (LTD; Bolshakov and Siegelbaum, 1994; Christie et al., 1996) forms of synaptic plasticity. As ubiquitous second messenger, $\mathrm{Ca}^{2+}$ has been shown to regulate gene expression (Berridge, 1998), membrane excitability (Sudhof, 2004), dendrite development (Lohmann and Wong, 2005; Redmond and Ghosh, 2005), synaptogenesis (Michaelsen and Lohmann, 2010), and many other processes contributing to the neuronal primary functions of information processing and memory storage (Berridge, 1998; Tanaka et al., 2008). The specificity of various biological outcomes is rendered possible by a complex protein network tightly regulating the amplitude, spatial, and temporal patterns of calcium movements through the neuronal cellular compartments. Under resting conditions neurons actively maintain a steep gradient between low intracellular free $\mathrm{Ca}^{2+}$ concentration $\left[\mathrm{Ca}^{2+}\right]_{\mathrm{i}}(0.1-0.5 \mu \mathrm{M})$ and high extracellular $\mathrm{Ca}^{2+}$ levels $(\sim 1 \mathrm{mM})$. $\left[\mathrm{Ca}^{2+}\right]_{\mathrm{i}}$ changes result from influx into the cell regulated through the opening of voltage-dependent $\mathrm{Ca}^{2+}$ channels (VDCCs), $N$-Methyl-D-Aspartate (NMDA) receptors, or transient receptor potential (TRP) channels located in the plasma membrane. Additionally $\left[\mathrm{Ca}^{2+}\right]_{\mathrm{i}}$ levels can be increased via ryanodine receptors (RyRs) and inositol-1,4,5-triphosphate receptors $\left(\mathrm{IP}_{3} \mathrm{Rs}\right)$ mediated release from endoplasmic reticulum intracellular $\mathrm{Ca}^{2+}$ stores, or by sodium-dependent $\mathrm{Ca}^{2+}$ $\left(\mathrm{Na}^{+} / \mathrm{Ca}^{2+}\right.$ exchanger) efflux from mitochondria. The return to basal $\left[\mathrm{Ca}^{2+}\right]_{\mathrm{i}}$ is achieved by $\mathrm{Ca}^{2+}$ extrusion (i.e., plasma membrane $\mathrm{Ca}^{2+}$-ATPase, sodium calcium exchanger), binding to $\mathrm{Ca}^{2+}$ buffering proteins (e.g., calmodulin, calcineurin, calbindin, calretinin), or organelle uptake (i.e., sarcoplasmic-endoplasmic reticulum $\mathrm{Ca}^{2+}$-ATPase, mitochondrial uniporter; Carafoli, 1987; Miller, 1991; Zaidi et al., 2003; Pivovarova and Andrews, 2010).

The purpose of this review is to provide a brief overview of the main types of neuronal $\mathrm{Ca}^{2+}$ channels and their role in neuronal plasticity. We will also discuss the participation of altered $\mathrm{Ca}^{2+}$ homeostasis to the cognitive decline observed during aging and the neurodegenerative process.

\section{PLASMA MEMBRANE $\mathrm{Ca}^{2+}$ CHANNELS}

Neuronal $\mathrm{Ca}^{2+}$ influx is primarily regulated through two types of plasma membrane $\mathrm{Ca}^{2+}$ channels: VDCCs and receptor-operated (ligand-gated) channels (ROCs).

\section{VOLTAGE-DEPENDENT $\mathrm{Ca}^{2+}$ CHANNELS}

Voltage-dependent $\mathrm{Ca}^{2+}$ channelss transduce electrical signals into local intracellular $\mathrm{Ca}^{2+}$ transients regulating intracellular processes such as neurotransmission, enzyme activation, gene expression, and neurite outgrowth or retraction (Tsien et al., 1988; Catterall, 2011). They are composed by an $\alpha 1_{1-10}$ subunit forming the $\mathrm{Ca}^{2+}$ selective channel, and several accessory subunits, $\alpha 2 \delta$, $\beta_{1-4}$, and $\gamma$ with anchorage, and regulatory functions. Based on their unique electrophysiological and pharmacological properties, and the type of $\alpha 1$ subunit VDCCs are divided into five classes: $\mathrm{Ca}_{\mathrm{v}} 1.1-\mathrm{Ca}_{\mathrm{v}} 1.4$ (L-type $\mathrm{Ca}^{2+}$ current), Ca 2.1 (P/Q-type Ca ${ }^{2+}$ current), $\mathrm{Ca}_{\mathrm{v}} 2.2$ (N-type $\mathrm{Ca}^{2+}$ current), $\mathrm{Ca}_{\mathrm{v}} 2.3$ (R-type $\mathrm{Ca}^{2+}$ current), and $\mathrm{Ca}_{\mathrm{v}} 3.1-3.3$ (T-type $\mathrm{Ca}^{2+}$ currents; Tsien et al., 1988; Catterall et al., 2005; Catterall, 2011).

In the mammalian brain $\mathrm{Ca}_{\mathrm{v}} 1.2$ and $\mathrm{Ca}_{\mathrm{v}} 1.3$ are the predominant forms of L-type $\mathrm{Ca}^{2+}$ channels. They are localized in the cell bodies and proximal dendrites, both at presynaptic as well as postsynaptic locations, forming small clusters on dendritic shafts 
and spines (Hell et al., 1993; Obermair et al., 2004) associated with regulatory proteins such as, protein kinase-A, A kinase anchoring proteins (AKAP15), calmodulin, and calcineurin (Davare et al., 2001). L-type channels have a high-voltage threshold for activation and are important for integrating synaptic inputs with the initiation of neurotransmitter release. Inward L-type $\mathrm{Ca}^{2+}$ currents can directly depolarize the membrane potential of neurons (Moyer and Disterhoft, 1994; Chan et al., 2007), or alternatively depress membrane excitability through coupling to $\mathrm{Ca}^{2+}$-activated $\mathrm{K}^{+}$ channels (Wisgirda and Dryer, 1994; Marrion and Tavalin, 1998). Because of their preferential cellular localization and interaction with $\mathrm{Ca}^{2+}$-binding regulatory proteins (they have been shown to regulate nuclear gene transcription (Dolmetsch, 2003; Oliveria et al., 2007). In addition, L-type channels are required for NMDA receptor-independent LTP at synapses between CA3 pyramidal neurons and mossy fibers, and between dentate gyrus and the basolateral nucleus of the amygdala (Grover and Teyler, 1990; Cavus and Teyler, 1996; Raymond and Redman, 2002, 2006; Niikura et al., 2004), spatial memory (Moosmang et al., 2005) and heterosynaptic plasticity (Lee et al., 2009; Rose et al., 2009). L-type $\mathrm{Ca}^{2+}$ currents leading to global dysregulated calcium signals have been implicated in aging and neurodegenerative disease (Chang et al., 2009). Enhanced activity of L-type $\mathrm{Ca}^{2+}$ channels is observed with neuronal aging (Thibault and Landfield, 1996) and their expression is increased in hippocampi of patients with Alzheimer's disease (AD) compared to healthy subjects (Coon et al., 1999). Blockage of Ltype currents has been shown to improve learning and memory in aged mice (Disterhoft and Oh, 2006), and in patients with dementia (Forette et al., 2002). In addition, inhibition of L-type channels reduces cell death in stroke (Korenkov et al., 2000) and Parkinson's disease (Chan et al., 2007). In young neurons, sustained depolarization or activation of NMDA receptors reduces L-type $\mathrm{Ca}^{2+}$ currents by internalization of $\mathrm{Ca}_{\mathrm{V}} 1.2$ channels trough a dynamindependent endocytosis mechanism, protecting the neurons from excitotoxic cell death (Green et al., 2007). It is thus possible that some of the impairments observed in neurons in aging and degenerative disorders are due to an altered regulation of $\mathrm{Ca}_{\mathrm{V}} 1.2$ and $\mathrm{Ca}_{\mathrm{v}} 1.3$ levels at the membrane.

$\mathrm{Ca}_{\mathrm{v}} 2.1$ (P/Q-type $\mathrm{Ca}^{2+}$ current) and $\mathrm{Ca}_{\mathrm{v}} 2.2$ (N-type $\mathrm{Ca}^{2+}$ current) channels are the predominant $\mathrm{Ca}^{2+}$-dependent pathway triggering fast release of neurotransmitters like glutamate, $\gamma$ aminobutyric acid (GABA), and acetylcholine (Olivera et al., 1994; Dunlap et al., 1995). $\mathrm{Ca}_{\mathrm{v}} 2$ are high-voltage threshold activated channels localized at presynaptic terminals, dendrites and cell bodies (Westenbroek et al., 1992). $\mathrm{Ca}_{\mathrm{v}} 2$ channels directly interact with the SNARE complex, formed by the vesicle-associated-v-SNARE protein synaptobrevin (VAMP/synaptobrevin) and two plasmamembrane-associated t-SNARE proteins, SNAP-25 and syntaxin1 (Bajjalieh and Scheller, 1995; Sudhof, 2004). The interaction occurs at a specific site, synprint, in the large intracellular loop connecting domains II and III of the $\alpha 1$ subunit of $\mathrm{Ca}_{\mathrm{v}} 2$ channels (Sheng et al., 1994; Retting et al., 1996). This association is $\mathrm{Ca}^{2+}$ dependent and regulated by protein phosphorylation of the synprint domain by protein kinase $\mathrm{C}$ (PKC) and $\mathrm{Ca}^{2+} /$ calmodulindependent protein kinase II (CaMKII; Sheng et al., 1996; Yokoyama et al., 2005). The same site is also responsible for the binding to synaptic vesicle $\mathrm{Ca}^{2+}$-binding protein synaptotagmin (Charvin et al., 1997; Wiser et al., 1997). During depolarization the presynaptic $\mathrm{Ca}_{\mathrm{v}} 2.1$ and $\mathrm{Ca}_{\mathrm{v}} 2.2$ channels open allowing the formation of high $\mathrm{Ca}^{2+}$ concentration microdomains in proximity of the pore (Stanley, 1997). $\mathrm{Ca}^{2+}$ then binds to synaptotagmin and the SNARE complex, resulting in the fusion of the vesicular membrane with the plasma membrane, and release of the neurotransmitter (Catterall and Few, 2008). Inhibition of presynaptic P/Q-types and $\mathrm{N}$-type currents with reduction of neurotransmitter release is typically produced by a positive shift in the voltage dependence and a slowing of channel activation (Bean, 1989). The G $\beta \gamma$ subunits released from receptor-coupled heteromeric G-proteins of the Gi/Go class are usually responsible for this inhibition by binding to the loop between domains I and II and the amino- and carboxy-terminal domains of $\mathrm{Ca}^{2+}$ channels (Herlitze et al., 1996; De Waard et al., 1997; Zamponi et al., 1997; Page et al., 1998; Li et al., 2004). Contrary to $\mathrm{Ca}_{\mathrm{v}} 2.1$ and $\mathrm{Ca}_{\mathrm{v}} 2.2, \mathrm{Ca}_{\mathrm{v}} 2.3$ (R-type $\mathrm{Ca}^{2+}$ current) channels control transmitter release with a lower efficacy (Wu et al., 1998). This is probably due to the fact the although they are localized at the cell body, dendrites and presynaptic terminal, their position is further away from the release sites (Yokoyama et al., 1995; Day et al., 1996; Wu et al., 1999). Nevertheless, Cav2.3 still carries one-third of the total calcium current at presynaptic terminals during a presynaptic action potential (Wu et al., 1998). Dietrich et al. (2003) showed that $\mathrm{Ca}^{2+}$ influx through presynaptic $\mathrm{Ca}_{\mathrm{v}} 2.3$ contributes to LTP without playing a role in the fast synaptic transmission or facilitation at specific hippocampal synapse terminals. It has been suggested that $\mathrm{Ca}_{\mathrm{V}} 2.3$ currents may be involved in control of gene expression or dendritic excitability (Delmas et al., 2000). Pathophysiological changes of $\mathrm{Ca}_{\mathrm{v}} 2$ channels have been associated with chronic disorders. Mutations in the $\mathrm{CACNA}_{1}$ A gene encoding the $\mathrm{Ca}_{\mathrm{v}} 2.1$ channels have been identified in patients affected by epileptic seizures, episodic ataxia type-2, spinocerebellar ataxia type-6, and familial hemiplegic migraine type 1 (Catterall et al., 2005; Cain and Snutch, 2011).

$\mathrm{Ca}_{\mathrm{v}} 3.1-3.3$ channels (T-type $\mathrm{Ca}^{2+}$ currents) are mainly distributed at cell bodies and dendrites of neurons in the olfactory bulb, amygdala, cerebellar cortex, hippocampus, thalamus, hypothalamus, and striatum (Talley et al., 1999). These channels play a critical role toward neuronal firing both in conducting $\mathrm{Ca}^{2+}$ during action potentials and in switching neurons between distinct rhythmic firing modes. T-types $\mathrm{Ca}^{2+}$ currents are activated at rather negative near resting membrane potentials (Huguenard, 1996). Specifically, they are activated during the initial depolarization phase although the highest conductance occur during the repolarization phase and return to resting membrane potential (McCobb and Beam, 1991). The $\mathrm{Ca}^{2+}$ entry through the $\mathrm{Ca}_{\mathrm{v}} 3.1-$ 3.3 channels leads to depolarization of the membrane allowing the generation of low threshold spikes that trigger bursts of $\mathrm{Na}$ dependent action potentials (Llinas, 1988). Depending on the specific channel subtype the time course of activation, inactivation, deactivation, and recovery from inactivation varies, resulting in unique biophysical properties and specific responses to action potential which can be extended during burst firing (Huguenard, 1996). Moreover the expression of individual or multiple $\mathrm{Ca}_{\mathrm{v}} 3$ subtypes and splice variants results in a variety of different burst patterns (Cain and Snutch, 2010). Bursts discharges controlled by T-type $\mathrm{Ca}^{2+}$ currents occur during physiological and pathological 
forms of neuronal rhythmicity (Huguenard, 1996) such as slow sleep oscillations ( $<1 \mathrm{~Hz}$; Crunelli et al., 2006), learning (Scotty et al., 2003) and hyper-synchronous oscillations during epilepsy (Zamponi et al., 2010). Mutations in the $\mathrm{CACNA}_{1} \mathrm{H}$ gene encoding the Cav3.2 channels have been linked to epilepsy and autism spectrum disorders (Heron et al., 2004; Splawski et al., 2006).

\section{RECEPTOR-OPERATED (LIGAND-GATED) CHANNELS}

Receptor-operated (ligand-gated) channels open in response to the binding of specific ligands, such as neurotransmitters to the extracellular domain of the receptor. The interaction causes a conformational change in the structure of the protein that leads to the opening of the channel pore and subsequent ion flux across the plasma membrane. Most ROCs are permeable to $\mathrm{Ca}^{2+}$ and represent an important mechanism for the generation of second messengers. Examples of ROCs include the glutamate receptors NMDA, $\alpha$-amino-3-hydroxy-5-methylisoxazole4-propionate acid (AMPA; Isaac et al., 2007; Paoletti, 2011), and kainate (KARs; Chittajallu et al., 1999), nicotinic acetylcholine receptors (nACh; Shen and Yakel, 2009), serotonin (5-HT 3 ) receptors (Yakel, 2000), and adenosine $5^{\prime}$-triphosphate (ATP) P2X receptors (Pankratov et al., 2008).

\section{Glutamate receptors}

Glutamate is the most abundant neurotransmitter in the central nervous system (CNS) playing an important role in neuronal physiology and pathology. At excitatory synapses glutamate release will primary activate the ionotropic receptors, NMDA, AMPA, and KARs allowing rapid influx of ions into the postsynaptic terminal.

NMDA receptors are permeable to $\mathrm{Na}^{+}$, which contributes to postsynaptic depolarization, and $\mathrm{Ca}^{2+}$, which generate $\mathrm{Ca}^{2+}$ transients and the ultimate intracellular physiological response. A unique feature of these receptors is that at resting potential the cation pore is blocked by extracellular $\mathrm{Mg}^{2+}$. Their activation thus relies upon glutamate binding to postsynaptic AMPA receptors and $\mathrm{Na}^{+}$and $\mathrm{Ca}^{2+}$ influx to cause a partial membrane depolarization sufficient to lift the $\mathrm{Mg}^{2+}$ blockage. Molecular cloning studies have identified several variants of the NMDA receptor subunits, NR1 $1-4 \mathrm{a} / \mathrm{b}$ and NR2 $2_{-D}$ (Hollmann and Heinemann, 1994). Each channel consists of two NR1 subunits, which are essential for the assembly of functional NMDA receptors, and two NR2 subunits that confer a unique set of characteristic upon the resultant NMDA receptor (Kutsuwada et al., 1992; Monyer et al., 1992). The cytoplasmic C-terminals of the NR1 and NR2 subunits link the receptor to a large multi-protein complex. This interaction facilitates the localization of the receptor in specific areas, such as the postsynaptic density (PSD), and the connection to a variety of downstream signaling molecules (Traynelis et al., 2010). In particular, NMDA-dependent $\mathrm{Ca}^{2+}$ influxes are known to regulate CREB-dependent gene transcription (Hardingham et al., 1999, 2001a,b; Impey and Goodman, 2001; Wu et al., 2001) which has considerable physiological relevance for the establishment of longterm synaptic plasticity and learning and memory (Barco et al., 2002). The robust activation of CREB is achieved via activation of the Ras-ERK1/2 and the nuclear $\mathrm{Ca}^{2+}$-calmodulin (CaM) kinase pathways (Hardingham et al., 2001b). Because CaM kinase activity itself is $\mathrm{Ca}^{2+}$-dependent (Bading and Greenberg, 1991; Finkbeiner and Greenberg, 1996) this pathway mediates CREB phosphorylation within the first few seconds of $\mathrm{Ca}^{2+}$ influx. On the other hand, the more upstream position of the $\mathrm{Ca}^{2+}$ dependent step (Ras) in the ERK1/2 pathway results in a slower yet prolonged activation after cessation of the synaptic input. The resulting CREB phosphorylation on Ser $^{133}$ allows the recruitment of the transcriptional co-activator, CREB-binding protein (CBP) to the target promoter (Chrivia et al., 1993). The trans-activating potential of CBP is further positively regulated by phosphorylation of $\mathrm{Ser}^{301}$ by either calmodulin (Deisseroth et al., 1998) or CaM kinase IV (Chrivia et al., 1993; Chawla et al., 1998; Hardingham et al., 1999) after elevation of nuclear $\mathrm{Ca}^{2+}$ (Impey et al., 2002). Growing evidence suggest that physiological levels of synaptic NMDA receptor activation may enhance resistance to trauma and promote survival of various neuronal types (Hardingham and Bading, 2010). Conversely, intense or chronic activation of extrasynaptic NMDA receptors has been implicated as the leading cause of neuronal death following acute traumas such as stroke, mechanical trauma, or seizure activity (Choi, 1990; Hardingham and Bading, 2010). Moreover, NMDA receptor activity is thought to contribute to the etiology of many chronic neurodegenerative disorders, such as Huntington's disease, HIV-associated dementia, and AD (Lancelot and Beal, 1998; Chohan and Iqbal, 2006; Fan and Raymond, 2007).

AMPA receptors are heterotetrameric structures composed of subunits encoded by four genes GluR1-4, and primarily conduct $\mathrm{Na}^{+}$and $\mathrm{K}^{+}$currents. The permeability to $\mathrm{Ca}^{2+}$ is regulated by the presence of GluR2 subunits. Only the AMPA receptors lacking GluR2 are permeable to $\mathrm{Ca}^{2+}$, although with reduced affinity compared to NMDA receptors (Dingledine et al., 1999). The GluR2 lacking AMPA receptors are widely expressed in the CNS (including interneurons, stellate, and glial cells) where they contribute to synaptic transmission and changes in synaptic efficacy (Isaac et al., 2007), as well as induce multiple forms of synaptic plasticity, including LTP (Gu et al., 1996; Jia et al., 1996; Kullmann and Lamsa, 2007; Liu and Zukin, 2007). Similarly to the NMDA receptor, $\mathrm{Ca}^{2+}$-permeable AMPA receptors signal to the nucleus to activate CREB (Perkinton et al., 1999; Tian and Feig, 2006) and other transcriptions factors. In response to $\mathrm{Ca}^{2+}$ transients both CaMKII and PKA phosphorylate specific AMPA subunits modifying the synaptic transmission strength (Lee and Kirkwood, 2011). Direct phosphorylation regulates the opening probability of the channels, as well as the insertion of the receptors into the postsynaptic membrane. During LTP phosphorylation increases the opening probability and the concentration of AMPA receptors at the synapse, whereas phosphorylation and receptor density decrease during LTD (Malenka, 2003).

KARs respond to kainate, glutamate, and, with very low affinity, to AMPA (Hollmann and Heinemann, 1994). KARs are tetrameric combinations of five subunits: GluK1, GluK2, GluK3, GluK4, and GluK5 (Hollmann and Heinemann, 1994; Collingridge et al., 2009). The GluK1-3 subunits are highly homologous and can form functional receptors as homotetramers, while GluK4-5 share only $45 \%$ homology with GluK1-3 and must combine with any of them in order to generate functional KARs (Herb et al., 1992). The receptor structure consist of extracellular N-terminal and ligand binding domains implicated respectively in subunit and ligand recognition, a transmembrane region, and intracellular 
re-entrant loop (p loop), forming the $\mathrm{Ca}^{2+}$ pore and C-terminal regions (Hollmann et al., 1994; Wo and Oswald, 1994). Similarly to the GluR2 subunit of AMPA receptors GluK2 and GluK3 can undergo RNA editing resulting in changes from a conserved glutamine $(\mathrm{Q})$ to an arginine $(\mathrm{R})$ in the channel pore loop that completely abolish $\mathrm{Ca}^{2+}$ permeability (Egebjerg and Heinemann, 1993; Kohler et al., 1993). KARs functions are much less understood that those of AMPA and NMDA receptors. They are located both pre- and postsynaptically, and based on genetic and pharmacological studies they appear to act mostly as modulators rather than obligatory components of synaptic transmission and neuronal excitability (Chittajallu et al., 1999; Contractor et al., 2011). KARs can regulate both excitatory and inhibitory synaptic transmission (Rodríguez-Moreno et al., 1997; Contractor et al., 2000; Kamiya and Ozawa, 2000; Schmitz et al., 2000; Frerking et al., 2001; Jiang et al., 2001). In the hippocampus, at mossy fiber CA3 pyramidal neuron synapses, endogenous activation of presynaptic kainate receptors increases the probability of glutamate release (Schmitz et al., 2001; Huettner, 2003). A similar regulatory role on excitatory transmission has been observed for other types of synapses in the central and peripheral nervous system (Pinheiro and Mulle, 2006). In addition to facilitation, presynaptic activation of KARs has also been shown to lead to inhibition of glutamate release (Kamiya and Ozawa, 1998; Rozas et al., 2003; Lauri et al., 2005, 2006; Jin et al., 2006). KARs-mediated bidirectional modulation has also been observed for the inhibitory transmitter GABA. KARs stimulation enhances GABA release at synapses between interneurons (Mulle et al., 2000; Cossart et al., 2001), yet it inhibits GABA release at interneuron-pyramidal cell connections (Clarke et al., 1997; Rodríguez-Moreno et al., 1997; Rodríguez-Moreno and Lerma, 1998). These opposite effects seem to rely on the fact that KARs signaling can occur either via ion influx, or by coupling of the receptor to G-proteins and activation of PKC dependent mechanisms (Melyan et al., 2002; Rozas et al., 2003; Ruiz et al., 2005). Overall it is believed that ionotopic activity accounts for enhanced neurotransmitter release, while inhibition is triggered by the metabotropic signaling pathway. In addition to neurotransmitter release, KARs contribute to temporal summation of postsynaptic depolarization in response to bursts of action potentials (Castillo et al., 1997; Vignes and Collingridge, 1997; Frerking and Ohlinger-Frerking, 2002; Jin et al., 2006), modulation of shortand LTP, as well as LTD, thus to learning and memory (Bortolotto et al., 1999; Contractor et al., 2001; Lauri et al., 2003; Schmitz et al., 2003; Campbell et al., 2007), nociception (Ko et al., 2005), synaptogenesis, and neuronal development (Lerma, 2006; Lauri and Taira, 2011).

As per pathological scenarios, KARs are considered to contribute to the induction and propagation of seizures (Ben-Ari, 1985). Although unequivocal involvement of KARs in human epilepsies still has to be established, KAR mutant mice display altered susceptibility to kainic acid induced seizures (Mulle et al., 1998; Vissel et al., 2001), and selective agonism of GluK1 blocks pilocarpine-induced epileptiform activity in hippocampal slices and seizures in vivo (Smolders et al., 2002). Like other glutamate receptors, KARs have been implicated in a variety of neurodegenerative conditions where glutamate excitotoxicity is believed to contribute to neuronal cell death. For example, GluK1 antagonists afford good neuroprotection in focal and global ischemic models (Bullock et al., 1994; Gill and Lodge, 1994; O’Neill et al., 1998, 2000). GluK2 genotype variations, and possibly excitotoxic mechanisms, have been linked to variations in the age of onset of Huntington's disease (Rubinsztein et al., 1997). Similar associations linking KARs with neuropsychiatric disorders have begun to emerge from various human genetic and post-mortem studies. KARs levels are reduced in bipolar and schizophrenic patients (Begni et al., 2002; Pickard et al., 2006; Wilson et al., 2006; Beneyto et al., 2007).

The human GluR6 KAR subunit, GRIK2, has been implicated in obsessive-compulsive disorder (Delorme et al., 2004), schizophrenia (Bah et al., 2004), and autism (Strutz-Seebohm et al., 2006). Human GluR7, GRIK3, and KA1 subunit, GRIK4, may be susceptible factors in major depressive disorders (Schiffer and Heinemann, 2007).

\section{Nicotinic acetylcholine receptors}

The $\mathrm{nACh}$ receptors are included in the cys-loop ligand-gated ion channel superfamily, and are activated by the endogenous neurotransmitter acetylcholine $(\mathrm{ACh})$, as well as nicotine, hence the name. The receptors are pentameric homo or hetero combinations of different subunits types, $\alpha 2-10, \beta 2-4$, with non-selective cation permeability and unique affinity to $\mathrm{Ca}^{2+}$ (Fucile, 2004). The nACh receptors are widely expressed in the brain at pre- and postsynaptic, as well as extrasynaptic loci (Dani and Bertrand, 2007). Presynaptic and pre-terminal nACh receptors enhance neurotransmitter release; postsynaptic nACh receptors contribute to fast excitatory transmission, while extrasynaptic nACh receptors influence neuronal excitability and/or intracellular processes (Dani and Bertrand, 2007). The nACh receptors play important modulatory roles in neuronal development and synaptic plasticity, participating in cognitive functions such as learning, memory, and attention (Levin and Simon, 1998; Mansvelder and McGehee, 2000; Sweatt, 2001). Inhibition of nACh receptors results in memory deficits, while the use of agonist has proved beneficial in different types of memory, such as short-term and working memory, both in animals and humans (Wallace and Porter, 2011). Furthermore, diminution, disruption, or alteration in the function of nACh receptors contributes to dysfunctions associated with various neurodegenerative pathologies, including epilepsy, Parkinson's disease, Alzheimer's disease, schizophrenia, autism, and addiction (Dani and Bertrand, 2007). The mechanisms underlying the effects of nACh receptors in synaptic plasticity are still poorly understood. In most cases nACh currents are thought to contribute to postsynaptic depolarization, enabling the activation of the VDCCs and subsequent $\mathrm{Ca}^{2+}$ influx, which augments the primary $\mathrm{Ca}^{2+}$ signals generated by the direct $\mathrm{Ca}^{2+}$ influx through nACh receptors (Dajas-Bailador et al., 2002). On the other hand, the predominant neuronal form, the homomeric $\alpha 7$ nACh receptor subtype has higher affinity for $\mathrm{Ca}^{2+}$ than $\mathrm{Na}^{+}$ (Shen and Yakel, 2009). Activation of $\alpha 7 \mathrm{nACh}$ receptors can thus generate $\mathrm{Ca}^{2+}$ transients via its channel pore sufficient to trigger $\mathrm{Ca}^{2+}$-induced $\mathrm{Ca}^{2+}$ release from ryanodine-dependent stores and downstream $\mathrm{Ca}^{2+}$-dependent intracellular processes independently of VDCCs activation (Sharma and Vijayaraghavan, 2001). 


\section{Serotonin receptor $\left(5-\mathrm{HT}_{3}\right)$}

$5-\mathrm{HT}_{3}$ is the only serotonin receptor acting as a ligand-gated ion channels rather than a metabotropic receptor. Similarly to nACh it belongs to the family of cys-loop ligand-gated ion channel (Maricq et al., 1991). Within the CNS, 5- $\mathrm{HT}_{3}$ receptors are highly expressed in brainstem areas, such as the area postrema and the nucleus of the solitary tract. Within the forebrain, $5-\mathrm{HT}_{3}$ receptors have been found in the entorhinal, frontal and cingulate cortices, hippocampus, and amygdala. Notably, despite clear pharmacological and physiological evidence that they affect dopamine neurotransmission, $5-\mathrm{HT}_{3}$ receptors are found at very low levels in areas such as striatum, substantia nigra, thalamus, or dorsal raphe nucleus (Kilpatrick et al., 1987; Tecott et al., 1993; Färber et al., 2004). 5- $\mathrm{HT}_{3}$ receptor consist of five subunits with an extracellular N-terminal domain containing the ligand recognition site for serotonin, four transmembrane domains (T2-T4), and a short intracellular C-terminal (Maricq et al., 1991). T2 is responsible for the formation of the channel pore, which conducts primarily $\mathrm{Na}^{+}$- and $\mathrm{K}^{+}$- and Ca ${ }^{2+}$ (Yang, 1990; Hargreaves et al., 1994), while the large intracellular loop between T3 and T4 is the site of protein kinase phosphorylation and alternative splicing (Maricq et al., 1991; Davies et al., 1999; Dubin et al., 1999). Of the five different isoforms cloned to date, $\mathrm{A}-\mathrm{E}$, only $5-\mathrm{HT}_{3 \mathrm{~A}}$ can generate functional homomeric receptors, all others isoforms must heteropentamerize with 5-HT 3 (Maricq et al., 1991; Davies et al., 1999; Dubin et al., 1999). The best characterized receptors are $5-\mathrm{HT}_{3 \mathrm{~A}}$ and $5-\mathrm{HT}_{3 \mathrm{AB}}$, with the homomeric form displaying lower single channel conductance, higher $\mathrm{Ca}^{2+}$ permeability, and slower kinetics of activation, deactivation, and desensitization (Davies et al., 1999; Hayrapetyan et al., 2005). The $5-\mathrm{HT}_{3}$ receptors are expressed both pre- and postsynaptically. Presynaptic $5-\mathrm{HT}_{3}$ receptors display high permeability to $\mathrm{Ca}^{2+}$ (Nichols and Mollard, 1996; Nayak et al., 1999), whereas postsynaptic receptors display a lower permeability to $\mathrm{Ca}^{2+}$ compared to $\mathrm{Na}^{+}$and $\mathrm{K}^{+}$(Yakel et al., 1990; Yang, 1990). Presynaptic 5- $\mathrm{HT}_{3}$ stimulation leads to opening of the ion channel, rapid membrane depolarization and release of various neurotransmitters, such as dopamine and GABA (Koyama et al., 2000; van Hooft and Vijverberg, 2000; Yakel, 2000). The activation of postsynaptic $5-\mathrm{HT}_{3}$ receptors contributes to fast excitatory synaptic transmission in various brain areas, such as the lateral amygdala (Sugita et al., 1992) and the visual cortex (Roerig et al., 1997). The best known physiological functions of $5-\mathrm{HT}_{3}$ receptors are the regulation of nausea and vomit (Fozard and Mobarok, 1978; Florczyk et al., 1982), and of mesocorticolimbic neurotransmission, which implicates these channels in the etiology of certain forms of drugs addiction (i.e., alcohol, cocaine; Engleman et al., 2008). In addition, modulation of $5-\mathrm{HT}_{3}$ receptors has also been suggested to have therapeutical relevance for schizophrenia, anxiety, cognition, and nociception (Thompson and Lummis, 2007).

\section{ATP P2X receptors}

The ionotropic $\mathrm{P} 2 \mathrm{X}$ receptors are channels that respond to extracellular ATP to induce membrane depolarization and $\mathrm{Ca}^{2+}$ influx. $\mathrm{P} 2 \mathrm{X}$ receptors are widely distributed pre- and postsynaptically on different cell types in the brain and spinal cord (Burnstock and Knight, 2004). Sensitivity to ATP, $\mathrm{Ca}^{2+}$ permeability, desensitization, recovery from desensitization kinetics, and other biophysical and pharmacological properties of the channels depend upon the subunit channel composition. Seven different subunits, $\mathrm{P} 2 \mathrm{x}_{1-7}$, can contribute to the generation of heterotrimers, or, with the exception of P2X6, homotrimers (Browne et al., 2010). P2X receptors display considerably high $\mathrm{Ca}^{2+}$ permeability, thus can mediate substantial $\mathrm{Ca}^{2+}$ influx despite the fact that the amplitude of $\mathrm{P} 2 \mathrm{X}$ mediated currents is quite modest when compared for example to glutamate-evoked responses (Pankratov et al., 2008). Because of this, $\mathrm{P} 2 \mathrm{X}$ are the main postsynaptic $\mathrm{Ca}^{2+}$ entry channels at resting potential when NMDA receptors are blocked by $\mathrm{Mg}^{2+}$ (Pankratov et al., 2003). P2X receptors can dynamically interact with other neurotransmitter receptors, including NMDA receptors, $\mathrm{GABA}_{\mathrm{A}}$ receptors, and nACh receptors (Surprenant and North, 2009). Activation of $\mathrm{P} 2 \mathrm{X}$ receptors has multiple modulatory effects on synaptic plasticity, either inhibiting or facilitating the longterm changes of synaptic strength depending on the physiological context; however the precise mechanisms of P2X-dependent regulation of synaptic plasticity remain elusive (Pankratov et al., 2008).

\section{INTRACELLULAR CALCIUM STORES}

It is well established that in addition to intracellular influx, global $\mathrm{Ca}^{2+}$ signals comprise release from intracellular stores either as a result of $\mathrm{Gq}$-coupled receptor activation, or secondary to the $\left[\mathrm{Ca}^{2+}\right]_{\mathrm{i}}$ rise itself. The largest intracellular store able to accumulate $\mathrm{Ca}^{2+}$ to concentrations of $10-100 \mathrm{mM}$ is the endoplasmic reticu$\operatorname{lum}(\mathrm{ER}) . \mathrm{ER} \mathrm{Ca}^{2+}$ release is mediated by RyRs, and by $\mathrm{IP}_{3} \mathrm{Rs}$. The function of the ER $\mathrm{Ca}^{2+}$ channels is to amplify or trigger $\mathrm{Ca}^{2+}$ rises initiated by the plasmalemma $\mathrm{Ca}^{2+}$ influx. In addition to the ER, mitochondria have also been shown to act as intracellular $\mathrm{Ca}^{2+}$ stores and play a prominent role in determining the shape, amplitude, and duration of the $\mathrm{Ca}^{2+}$ transients.

\section{ENDOPLASMIC RETICULUM CALCIUM REGULATION}

In neurons the ER is represented by a complex system of folded membranes extending from the nuclear envelope throughout perikaryon, axon (Henkart et al., 1978), presynaptic terminals (McGraw et al., 1980), dendrites, and dendritic spines (Satoh et al., 1990). Since the first demonstrations of its $\mathrm{Ca}^{2+}$ sequestering ability in squid giant axon (Henkart et al., 1978) and rat synaptosomes (McGraw et al., 1980), the ER has been the object of intensive studies in order to determine its role in neuronal $\mathrm{Ca}^{2+}$ homeostasis (Andrews et al., 1988; Markram et al., 1995). It is now evident that $\mathrm{ER} \mathrm{Ca}^{2+}$ regulation plays important functions in neuronal physiology and plasticity regulating synaptic transmission both at the presynaptic and postsynaptic terminals (Berridge, 1998; Park et al., 2008). Notably, at the level of dendritic spines, the ER comes in contact with the postsynaptic density thanks to the protein Homer simultaneously binding $\mathrm{IP}_{3} \mathrm{Rs}$ on the ER, and group 1 metabotropic receptors at the plasma membrane (Tu et al., 1998). Similar juxtaposition are also observed in other areas of the neuron and are believed to regulate extracellular $\mathrm{Ca}^{2+}$ entry through store operated channels or membrane excitability via activation of $\mathrm{K}^{+}$channels (Benedeczky et al., 1994; Berridge, 2002). ER $\mathrm{Ca}^{2+}$ homeostasis relies upon Sarco/endoplasmic-reticulum $\mathrm{Ca}^{2+}$ ATPase (SERCA) pumps and binding proteins regulating respectively $\mathrm{Ca}^{2+}$ uptake from the cytosol and $\mathrm{Ca}^{2+}$ sequestration (Prins 
and Michalak, 2011; Vandecaetsbeek et al., 2011). Conversely, $\mathrm{Ca}^{2+}$ efflux from the ER is achieved though input activated $\mathrm{IP}_{3} \mathrm{Rs}$ and RyRs release or $\mathrm{Ca}^{2+}$ leak. The importance of the $\mathrm{ER} \mathrm{Ca}^{2+}$ homeostasis in brain physiology can be easily appreciated considering the number of neurodegenerative disorders have been linked to alterations with its various components (Mattson, 2007).

\section{Ryanodine receptors}

To date, three mammalian isoforms of RyRs have been isolated displaying unique differential expression in the CNS. RyR1 is found exclusively in Purkinje cells in the cerebellum (Furuichi et al., 1994), RyR2 is highly expressed in Purkinje cells and the cerebral cortex (Sharp et al., 1993; Furuichi et al., 1994), while RyR3 has a wider distribution and is also present in hippocampus, thalamus, and striatum (Hakamata et al., 1992). RyRs are homotetramers and the largest known ion channels with a mass greater than $2 \mathrm{MDa}$, a fact that have challenged the analysis and molecular understanding of their function. Nevertheless, in recent years it has been shown that due to their close physical interaction with $\mathrm{Ca}_{\mathrm{v}}$ 1.1-1.2 L-type $\mathrm{Ca}^{2+}$ channels, RyRs directly support $\mathrm{Ca}^{2+}$-induced $\mathrm{Ca}^{2+}$ release (CIRC) as consequence of $\mathrm{Ca}^{2+}$ influx through VDCCs or ROCs (Chavis et al., 1996). Cytosolic and luminal $\mathrm{Ca}^{2+}$ levels are the principal direct and indirect regulators of RyRs functions (Meissner, 2002). RyRs have multiple cytosolic allosteric $\mathrm{Ca}^{2+}$ binding sites, and in absence of other effectors are maximally activated at cytosolic $\mathrm{Ca}^{2+}$ concentrations of $1-10 \mu \mathrm{M}$, while they are inhibited in the low millimolar range (Bezprozvanny et al., 1991). Luminal $\mathrm{Ca}^{2+}$ content has also been shown to modify the availability and open probability of RyRs (Shmigol et al., 1996), possibly by both direct interaction with luminal $\mathrm{Ca}^{2+}$ regulatory sites (Sitsapesan and Williams, 1995), and by binding to the cytoplasmic sites after permeating through the pore (Tripathy and Meissner, 1996; Laver, 2007). RyRs-dependent $\mathrm{Ca}^{2+}$ release is also potentiated by ATP and other adenine nucleotides (Meissner, 1984). Furthermore, as components of a regulatory macromolecular complex with PKA, FKBP12, FKBP12.6, calsequestrin, triadin, and junction, calmodulin and CaMKII are responsible for most of the indirect effects of $\mathrm{Ca}^{2+}$ on RyRs. Calmodulin binds all three forms of RyRs, both in its $\mathrm{Ca}^{2+}$-free (ApoCaM) and $\mathrm{Ca}^{2+}$ bound forms (CaCaM; Tripathy et al., 1995; Yamaguchi et al., 2005). ApoCaM is a partial agonist whereas $\mathrm{CaCaM}$ is an inhibitor (Rodney et al., 2000). In Drosophila melanogaster, CaMKII activation and RyRs-dependent $\mathrm{Ca}^{2+}$ release are fundamental for posttetanic potentiation of neurotransmitter secretion (Shakiryanova et al., 2007). In addition to neurotransmitter release (Mothet et al., 1998), RyRs also regulate action potential hyperpolarization (Kawai and Watanabe, 1989) and axonal retrograde transport (Breuer et al., 1992). In hippocampus (Reyes and Stanton, 1996) and in Purkinje cells (Kohda et al., 1995), LTD has been shown to be RyRs-sensitive $\mathrm{Ca}^{2+}$ stores dependent. Despite the evidence suggesting a potential role in synaptic plasticity behavioral testing in RyR knock out mice have given discrepant results. Balschun et al. (1999) observed equivalent learning ability in RyRs knock out and wild-type animals. However, in the same knock out model others have reported facilitated CA1 LTP induction after short tetanic stimulation, absence of LTD and improved spatial ability (Futatsugi et al., 1999), as well as impairments of performance in the contextual fear conditioning test, passive avoidance test, and Y-maze (Kouzu et al., 2000).

\section{Inositol-1,4,5-triphosphate receptors}

Following activation of $\mathrm{G} q$-coupled or tyrosine kinase receptors by their ligands (i.e., hormones, growth factors, neurotransmitters) the activation of phospholipases leads to the cleavage of phosphatidylinositol 4,5-biphosphate and generation of second messengers diacylglycerol and inositol-1,4,5-triphosphate $\left(\mathrm{IP}_{3}\right)$ that can easily diffuse from the plasma membrane through the cell. Unique amongst the various cellular second messengers $\mathrm{IP}_{3}$ binds and activates an intracellular ligand-gated $\mathrm{Ca}^{2+}$ channel, $\mathrm{IP}_{3} \mathrm{R}$. In mammals the receptor is an homo- or hetero-tetramer formed by the product of three $\mathrm{IP}_{3} \mathrm{R}$ genes $\left(\mathrm{IP}_{3} \mathrm{R} 1-3\right)$. Each gene is translated as several splicing variants, and its expression can be modulated by various stimuli providing an impressive level of channel diversity (Foskett et al., 2007). Like RyRs the cytosolic portion of the $\mathrm{IP}_{3} \mathrm{Rs}$ provides scaffold to a host of regulatory proteins creating macromolecular complexes able to receive inputs from the majority of the signaling pathways, as well as to sense metabolic changes within the cell. The various receptor subtypes display different binding affinities for $\mathrm{IP}_{3}$ with $\mathrm{IP}_{3} \mathrm{R} 2$ being more sensitive than $\mathrm{IP}_{3} \mathrm{R} 1$, and both considerably more sensitive than $\mathrm{IP}_{3} \mathrm{R} 3$ (Iwai et al., 2005). The binding of $\mathrm{IP}_{3}$ not only controls channel opening, but it is also necessary for its time dependent inactivation (Mikoshiba, 2007), and clustering of the receptors (Taylor et al., 2009). IP $_{3}$ R-evoked $\mathrm{Ca}^{2+}$ signals can operate locally or globally thanks to the hierarchical recruitment of elementary $\mathrm{Ca}^{2+}$ release events, and ability to form clusters. The smallest event known as " $\mathrm{Ca}^{2+}$ blip" is likely the result of the random opening of single $\mathrm{IP}_{3} \mathrm{R}$, last about $130 \mathrm{~ms}$ and causes very small increases of cytosolic $\mathrm{Ca}^{2+}(<50 \mathrm{nM}) . \mathrm{Ca}^{2+}$ puffs are larger (50-600 nM) and longer lasting events spreading few micrometers, and are caused by the near-simultaneous opening of several clustered $\mathrm{IP}_{3} \mathrm{Rs}$ (Bootman and Berridge, 1996). If the inducing stimulus persist the frequency of $\mathrm{Ca}^{2+}$ puffs increases, and can originate regenerative $\mathrm{Ca}^{2+}$ waves as the $\mathrm{Ca}^{2+}$ diffusing from one site ignites the activity of another receptor (Berridge, 1997). In addition to $\mathrm{IP}_{3}$ the activation of the receptor requires $\mathrm{Ca}^{2+}$ as co-agonist (Finch et al., 1991). It is well established that cytosolic $\mathrm{Ca}^{2+}$ regulates $\mathrm{IP}_{3}$ Rs activity in a biphasic fashion, with isotype differences in the stimulatory and inhibitory ranges (Foskett et al., 2007; Mikoshiba, 2007). While it is overall agreed that modest increases in cytosolic $\mathrm{Ca}^{2+}$ enhance responses to $\mathrm{IP}_{3}$ and higher concentrations inhibit it, the modalities of $\mathrm{Ca}^{2+}$ regulation are still unclear. Both direct regulation via binding to stimulatory or inhibitory sites on the channel structure, and indirect regulation through one of the accessory regulatory proteins have been proposed (Taylor et al., 2004). Luminal levels of $\mathrm{Ca}^{2+}$ are also known to impact gating of $\mathrm{IP}_{3}$ Rs via mechanisms involving $\mathrm{Ca}^{2+}$ binding and interaction with chaperones such as calnexin and HRp44 (Higo et al., 2005). As seen with other $\mathrm{Ca}^{2+}$ channels, $\mathrm{IP}_{3} \mathrm{R}$ activity is as well modified by phosphorylation (Foskett et al., 2007), ATP levels (Mak et al., 1999, 2001), redox status (Higo et al., 2005), and interaction with other proteins (Patterson et al., 2004; Foskett et al., 2007). One significant example is the interaction between $\mathrm{IP}_{3} \mathrm{R} 1$ and the voltage-dependent anion channels (VDACs) located in the mitochondria outer membrane (Szabadkai et al., 2006), 
which facilitates mitochondrial $\mathrm{Ca}^{2+}$ uptake. Over the past decade, thanks to the generation of $\mathrm{IP}_{3} \mathrm{R}$ knock out mice models it has been established that $\mathrm{IP}_{3} \mathrm{Rs}$ play a crucial role in brain functions, enhancing neurotransmitter release following repetitive stimulation (Emptage et al., 2001), neurite formation and extension during development (Takei et al., 1998), hippocampal LTP (Fujii et al., 2000), cerebellar LTD (Inoue et al., 1998), learning, memory, and behavior (Matsumoto et al., 1996; Fujii et al., 2000; Nishiyama et al., 2000).

\section{Presenilins as endoplasmic reticulum $\mathrm{Ca}^{2+}$ leak channels}

The steady state $\mathrm{Ca}^{2+}$ within the lumen of the ER is maintained by balancing the influx created by SERCA pumps with "leak" mechanisms. In neurons, the addition of SERCA pumps inhibitors results in an immediate drop of the luminal $\mathrm{Ca}^{2+}$, implying the existence of leak channels (Solovyova et al., 2002; Verkhratsky, 2005). In muscle cells it has been shown that RyRs under conditions causing their uncoupling from the luminal $\mathrm{Ca}^{2+}$ binding proteins can function as leak channels (Mark et al., 1998, 2000). The molecular identity of the ER leak channels under physiological conditions is still unresolved. However, recent evidence points to presenilins (PSs) as potential physiological ER $\mathrm{Ca}^{2+}$ leak channels (Tu et al., 2006; Nelson et al., 2007). Presenilin 1 and 2 are integral ER transmembrane proteins (Annaert et al., 1999) undergoing endoproteolytic cleavage that generates $\mathrm{N}$-terminal and C-terminal fragments. The cleaved PSs fragments assemble in a complex with nicastrin, anterior pharynx defective 1 , and presenilin enhancer 2 , translocate to the plasma membrane where they function as the $\gamma$-secretase enzyme responsible of the amyloid precursor protein (APP) cleavage generating amyloid $\beta$, the primary component of amyloid plaques in AD (De Strooper et al., 1998; De Strooper and Annaert, 2010). Since the discovery that PSs mutations account for the majority of familiar forms of $\mathrm{AD}$, PSs have been intensively studied (Levy-Lahad et al., 1995; Rogaev et al., 1995; Sherrington et al., 1995). Together with the understanding of their role in the APP processing come the evidence that they participate to ER $\mathrm{Ca}^{2+}$ homeostasis. Evidence of deregulated ER $\mathrm{Ca}^{2+}$ signaling has been gathered from various experimental systems including human fibroblasts from $\mathrm{AD}$ patients and transgenic mouse models carrying PSs mutations (Ito et al., 1994; Guo et al., 1996, 1999; Leissring et al., 1999a,b; Stutzmann et al., 2004, 2006). The mechanisms proposed to explain PSs functions in $\mathrm{Ca}^{2+}$ homeostasis are based on physical interactions and indirect influence on others ER $\mathrm{Ca}^{2+}$ players, such as RyRs (Chan et al., 2000; Stutzmann et al., 2006), IP 3 Rs (Cai et al., 2006; Cheung et al., 2008), SERCA pumps (Green et al., 2008), as well as on the influence on store operated $\mathrm{Ca}^{2+}$ influx (Leissring et al., 2000). However, recent experiments using planar lipid bilayers and neurons from double knock out PS1/PS2 and triple transgenic AD mice, showed that PSs themselves form low conductance $\mathrm{Ca}^{2+}$ channels responsible for about $80 \%$ of the passive $\mathrm{Ca}^{2+}$ leak from the ER (Tu et al., 2006; Nelson et al., 2007). This ER Ca ${ }^{2+}$ leak function appears to be independent from the $\gamma$-secretase activity, and is lost in most of the familiar AD PSs mutants studied to date resulting in $\mathrm{ER} \mathrm{Ca}^{2+}$ overload (Tu et al., 2006; Nelson et al., 2007; Bezprozvanny and Mattson, 2008). Regardless of the type of mechanisms, a role for PSs in synaptic plasticity, learning, and memory via regulation of $\mathrm{Ca}^{2+}$ signaling has been well established.
PSs regulates homeostatic synaptic scaling (Pratt et al., 2011), neurotransmitter release from the presynaptic terminal (Zhang et al., 2009), LTP (Zhang et al., 2010), and the establishment of hippocampal memory (Saura et al., 2004).

\section{MITOCHONDRIA AND CALCIUM}

Thanks to their ability to rapidly uptake large quantities of $\mathrm{Ca}^{2+}$, mitochondria contribute to shaping the amplitude and duration of cytosolic $\mathrm{Ca}^{2+}$ signaling (Deluca and Engstrom, 1961; Vasington and Murphy, 1962). Structural dynamic junctions link the mitochondria to the ER, facilitating the signal transduction, and biosynthetic interplay existing between the two organelles (Csordás et al., 2006; Hayashi et al., 2009; Rizzuto et al., 2009; de Brito and Scorrano, 2010). Amongst the proteins identified as possible components of the ER-mitochondria coupling complexes are glucose-related protein 75 (Szabadkai et al., 2006), sigma-1 receptor (Hayashi and Su, 2007), mitofusin-2 (de Brito and Scorrano, 2009), phosphofurin acidic cluster sorting protein 2 (Simmen et al., 2005), BAP-31 (Wang et al., 2000), and dynamin like protein 1 (Pitts et al., 1999). These interactions regulate the trafficking of phospholipids, as well as the $\mathrm{Ca}^{2+}$ interchanges between the $\mathrm{ER}$ and the mitochondria. $\mathrm{Ca}^{2+}$ can cross both the outer and inner mitochondrial membranes to enter the matrix, using different pathways. The mitochondrial $\mathrm{Ca}^{2+}$ influx is a tightly controlled process, because under physiological concentrations $\mathrm{Ca}^{2+}$ modulates pyruvate, isocitrate, and $\alpha$-ketoglutarate dehydrogenases, thus the Krebs cycle (Denton et al., 1980; Hansford, 1980) and the production of ATP (Jouaville et al., 1999). The predominant mechanism of intake through the outer membrane is represented by high conductance and high-density VDACs channels (McEnery et al., 1993; Lee et al., 1998). The inner membrane $\mathrm{Ca}^{2+}$ import is primarily regulated through the mitochondrial $\mathrm{Ca}^{2+}$ uniporter (MCU) composed by a protein forming the channel itself (Baughman et al., 2011; De Stefani et al., 2011), and the accessory protein MICU1 regulating its function (Perocchi et al., 2010). The MCU allows the ion transport down its electrochemical gradient and it is functional only at high extra mitochondrial $\mathrm{Ca}^{2+}$ concentrations. Rapid $\mathrm{Ca}^{2+}$ intake independent from the electrochemical gradient is achieved through mitochondrial RyR (Beutner et al., 2001), and the rapid mode mitochondrial $\mathrm{Ca}^{2+}$ transport (Sparagna et al., 1995). Both systems operate at low physiological $\mathrm{Ca}^{2+}$ levels while they are inactivated at concentrations causing the activation of MCU. $\mathrm{Ca}^{2+}$ efflux is mostly dependent on the mitochondrial $\mathrm{Na}^{+} / \mathrm{Ca}^{2+}$ exchanger that couples $\mathrm{Ca}^{2+}$ extrusion with the inward directed $\mathrm{Na}^{+}$electrochemical gradient (Carafoli et al., 1974; Palty et al., 2010), and possibly by the transient openings of the permeability transition pore (PTP). The high conductance channel is a complex of yet non-identified molecular components, that once opened allows indiscriminate exchange of ions and solutes between the cytosol and the mitochondrial matrix. VDACs on the outer membrane, adenine nucleotide transferase on the inner one, and cyclophilin D in the matrix, have been proposed as possible channel components, but studies from knock out mice have raised doubts on their role as obligatory constituents of the PTP (Rizzuto et al., 2009). The opening of the PTP channel is induced by high matrix $\mathrm{Ca}^{2+}$, free radicals, adenine nucleotide depletion, $\mathrm{pH}$, and decreased mitochondrial membrane potential (Halestrap, 2009). The process is reversible, yet under non-physiological conditions 
the PTP can become fixed in the open conformation leading to apoptotic cell death via release of apoptotic factors such as cytochrome $c$, apoptosis-inducing factor and Smac/Diablo, or necrotic cell death via massive ATP depletion (Abou-Sleiman et al., 2006; Leung and Halestrap, 2008). Finally the $\mathrm{Ca}^{2+} / \mathrm{H}^{+}$uniporter Letm 1 can move $\mathrm{Ca}^{2+}$ in or out of the mitochondria in a $\mathrm{Ca}^{2+}$ and pH-gradient dependent manner (Jiang et al., 2009).

Neuronal synapse are highly enriched with mitochondria in order to fulfill the high energy requirements needed to fuel the active processes required for synaptic transmission, and to serve as $\mathrm{Ca}^{2+}$ sinks and modulators following $\mathrm{Ca}^{2+}$ entry (David and Barrett, 2000; Tsang et al., 2000). The local ATP production by mitochondria alone is important to maintain synaptic transmission. Impairment of mitochondria transport into the presynaptic terminal have been shown to cause abnormal neurotransmission during intense stimulation (Verstreken et al., 2005), impaired presynaptic short-term plasticity, and accelerated synaptic depression under high-frequency firing (Ma et al., 2009). Furthermore, genetically engineered mice with decrease mitochondrial respiratory function displayed altered retention and consolidation of spatial memory (Tanaka et al., 2008). As per the $\mathrm{Ca}^{2+}$ regulatory function, mice lacking mitochondrial VDACs show impaired fear conditioning and spatial learning, and deficits in long and short-term hippocampal synaptic plasticity (Weeber et al., 2002). Tetanus-induced synaptic potentiation, contrary to other forms of synaptic plasticity, does not require $\mathrm{Ca}^{2+}$ influx into the cell, but rather depend on $\mathrm{Na}^{+}$influx into the nerve terminals to promote $\mathrm{Ca}^{2+}$ efflux from mitochondria through the $\mathrm{Na}^{+} / \mathrm{Ca}^{2+}$ exchanger (Tang and Zucker, 1997; Yang et al., 2003). Additionally, while the majority of synapses requires the cooperation between $\mathrm{ER}$ and mitochondria to regulate $\mathrm{Ca}^{2+}$ signaling (Rizzuto et al., 2004), mitochondria appear to be the main $\mathrm{Ca}^{2+}$ regulating system, with minimal uptake into the ER during substained prolonged stimulation in specialized structures, like the neuromuscular junction (David and Barrett, 2003) and the calyx of Held (Billups and Forsythe, 2002).

\section{CALCIUM AGING AND NEURODEGENERATION}

The plasticity of the nervous system depends at any time point on the balance between degenerative and regenerative processes. Because $\mathrm{Ca}^{2+}$ is a fundamental signaling mechanism involved in almost all cellular physiological functions, subtle alterations of its homeostasis lead to profound functional changes. Several lines of evidence support the notion that $\mathrm{Ca}^{2+}$ dyshomeostasis is implicated in normal brain aging (Gibson and Peterson, 1987; Disterhoft et al., 1994; Khachaturian, 1994). The cognitive decline occurring with normal aging is not associated with significant neuronal loss (Gallagher et al., 1996), but is rather the result of changes in synaptic connectivity. Age-dependent alterations have been observed for multiple components the $\mathrm{Ca}^{2+}$ cellular machinery, and appear to strongly correlate with cognitive deficits (Power et al., 2002; Rosenzweig and Barnes, 2003). Aged hippocampal neurons display decreased synaptic plasticity with increased $\mathrm{Ca}^{2+}$ influx and density of L-type VDCCs (Campbell et al., 1996; Thibault and Landfield, 1996; Thibault et al., 2001). The increase could arise from altered gene or protein expression
(Herman et al., 1998), or phosphorylation changes of the L-type $\mathrm{Ca}^{2+}$ channels (Norris et al., 2002; Davare and Hell, 2003). GluR2 and NR1 protein expression is reduced in hippocampus (Liu et al., 2008; Yu et al., 2011) and postrhinal and entorhinal cortex of aged rats (Liu et al., 2008). Additionally, aged neurons show enhanced CIRC due to the increased $\mathrm{ER} \mathrm{Ca}^{2+}$ release (Kumar and Foster, 2004; Gant et al., 2006), diminished $\mathrm{Ca}^{2+}$ extrusion through the plasma membrane ATPase (Michaelis et al., 1996; Gao et al., 1998), reduced cellular $\mathrm{Ca}^{2+}$ buffering capacity due to impairment of the SERCA pumps (Murchison and Griffith, 1999), and diminished mitochondrial $\mathrm{Ca}^{2+}$ sink capability (Xiong et al., 2002; Murchison et al., 2004), activation of calcineurin (Foster et al., 2001), and calpains (Nixon et al., 1994). The overall result is an increase of $\mathrm{Ca}^{2+}$ loads which negatively impact neuronal $\mathrm{Ca}^{2+}$-dependent $\mathrm{K}^{+}$channel slow after-hyperpolarization and excitability (Landfield and Pitler, 1984; Khachaturian, 1989; Matthews et al., 2009), increases the threshold frequency for induction of LTP (Shankar et al., 1998; Ris and Godaux, 2007), enhances the susceptibility to induction of LTD (Norris et al., 1996; Kumar and Foster, 2005; Lee et al., 2005), and ultimately learning and memory. The idea that $\mathrm{Ca}^{2+}$ dyshomeostasis is a key factor in determining brain aging is substantiated by various studies using pharmacological interventions aimed at counteracting the agerelated $\mathrm{Ca}^{2+}$ signaling increase (Foster, 2006). Administration of BAPTA-AM, a membrane-permeant $\mathrm{Ca}^{2+}$ chelator, ameliorates impaired presynaptic cytosolic, and mitochondrial $\mathrm{Ca}^{2+}$ dynamics in hippocampal CA1 synapses of old rats (Tonkikh and Carlen, 2009), and enhances spatial learning (Tonkikh et al., 2006). Similarly, the L-type $\mathrm{Ca}^{2+}$ channel blocker nimodipine counteracts age-related learning impairments in rabbits (Deyo et al., 1989; Kowalska and Disterhoft, 1994), rodents (Levere and Walker, 1992; Ingram et al., 1994), non-human primates (Sandin et al., 1990), and elderly patients with dementia (Ban et al., 1990; Tollefson, 1990). Aging is the greatest risk factor for neurodegenerative disorders, a heterogenous group of pathologies characterized by the gradual neuronal loss in motor, sensory, or cognitive systems. While per se not cause of neuronal loss, the age-dependent alterations of $\mathrm{Ca}^{2+}$ signaling can possibly enhance neuronal vulnerability to metabolic and functional stressors thus contribute to the initiation or progression of the neurodegenerative process (Toescu et al., 2004; Toescu and Vreugdenhil, 2010). Despite intrinsic different etiologies, dysregulated $\mathrm{Ca}^{2+}$, and mitochondrial homeostasis have emerged as common underlying molecular mechanisms of neuronal loss in Alzheimer's, Parkinson's, Huntington's diseases, amyotrophic lateral sclerosis and other neurodegenerative disorders (Mattson, 2004, 2007; Bezprozvanny, 2009). The specificity of $\mathrm{Ca}^{2+}$ homeostatic and signaling machineries requirements that underlie the unique responses to the same stimuli of different neurons, accounts, at least partially, for the selective impairment of neuronal subtypes and brain areas observed during aging and neurodegeneration. While the sequence of pathological events and the kinetics of degeneration are still not completely understood, and likely differ amongst the various disorders, decreased mitochondrial functional capacity with diminished ATP production (Navarro, 2004) and increased reactive oxygen species generation (Floyd and Hensley, 2002), together with mitochondrial reduced $\mathrm{Ca}^{2+}$ buffering ability (Xiong et al., 2002), and enhanced $\mathrm{Ca}^{2+}$ 
responses are common key elements to ignite the necrotic or apoptotic cell death distinctive of most neurodegenerative disorders (Green and Kroemer, 2004; Lin and Beal, 2006).

\section{REFERENCES}

Abou-Sleiman, P. M., Muqit, M. M., and Wood, N. W. (2006). Expanding insights of mitochondrial dysfunction in Parkinson's disease. Nat. Rev. Neurosci. 7, 207-219.

Andrews, S. B., Leapman, R. D., Landis, D. M., and Reese, T. S. (1988). Activity-dependent accumulation of calcium in Purkinje cell dendritic spines. Proc. Natl. Acad. Sci. U.S.A. 85, 1682-1685.

Annaert, W. G., Levesque, L., Craessaerts, K., Dierinck, I., Snellings, G., Westaway, D., George-Hyslop, P. S., Cordell, B., Fraser, P., and De Strooper, B. (1999). Presenilin 1 controls gamma-secretase processing of amyloid precursor protein in pre-golgi compartments of hippocampal neurons. J. Cell Biol. 147, 277-294.

Bading, H., and Greenberg, M. E. (1991). Stimulation of protein tyrosine phosphorylation by NMDA receptor activation. Science 253, 912-914.

Bah, J., Quach, H., Ebstein, R. P., Segman, R. H., Melke, J., Jamain, S., Rietschel, M., Modai, I., Kanas, K., Karni, O., Lerer, B., Gourion, D., Krebs, M. O., Etain, B., Schürhoff, F., Szöke, A., Leboyer, M., and Bourgeron, T. (2004). Maternal transmission disequilibrium of the glutamate receptor GRIK2 in schizophrenia. Neuroreport 15, 1987-1991.

Bajjalieh, S. M., and Scheller, R. H. (1995). The biochemistry of neurotransmitter secretion. J. Biol. Chem. 270, 1971-1974.

Balschun, D., Wolfer, D. P., Bertocchini, F., Barone, V., Conti, A., Zuschratter, W., Missiaen, L., Lipp, H. P., Frey, J. U., and Sorrentino, V. (1999). Deletion of the ryanodine receptor type 3 (RyR3) impairs forms of synaptic plasticity and spatial learning. EMBO J. 18, 5264-5273.

Ban, T. A., Morey, L., Aguglia, E., Azzarelli, O., Balsano, F., Marigliano, V., Caglieris, N., Sterlicchio, M., Capurso, A., Tomasi, N. A., Cerepaldi, G., Volpe, D., Palmieri, G., Ambrosi, G., Polli, E., Cortellano, M., Zanussi, C., and Froldi, M. (1990). Nimodipine in the treatment of old age dementias. Prog. Neuropsychopharmacol. Biol. Psychiatry 14, 525-551.

Barco, A., Alarcon, J. M., and Kandel, E. R. (2002). Expression of constitutively active CREB protein facilitates tion by enhancing synaptic capture. Cell 108, 689-703.

Baughman, J. M., Perocchi, F., Girgis, H. S., Plovanich, M., Belcher-Timme, C. A., Sancak, Y., Bao, X. R., Strittmatter, L., Goldberger, O., Bogorad, R. L., Koteliansky, V., and Mootha, V. K. (2011). Integrative genomics identifies MCU as an essential component of the mitochondrial calcium uniporter. Nature 476, 342-345.

Bean, B. P. (1989). Neurotransmitter inhibition of neuronal calcium currents by changes in channel voltage dependence. Nature 340, 153-156.

Begni, S., Popoli, S., Moraschi, S., Bignotti, S., Tura, G. B., and Gennarelli, M. (2002). Association between the ionotropic glutamate receptor kainate 3 (GRIK3) ser310ala polymorphism and schizophrenia. Mol. Psychiatry 7, 416-418.

Ben-Ari, Y. (1985). Limbic seizure and brain damage produced by kainic acid: mechanisms and relevance to human temporal lobe epilepsy. Neuroscience $14,375-403$.

Benedeczky, I., Molnar, E., and Somogyi, P. (1994). The cisternal organelles as a $\mathrm{Ca}(2+)$-storing compartment associated with GABAergic synapses in the axon initial of hippocampal pyramidal neurons. Exp. Brain Res. 101, 216-230.

Beneyto, M., Kristiansen, L. V., OniOrisan, A., McCullumsmith, R. E., and Meador-Woodruff, J. H. (2007). Abnormal glutamate expression in the medial temporal lobe in schizophrenia and mood disorders. Neuropsychopharmacology 32, 188801902.

Berridge, M. J. (1997). Elementary and global aspects of calcium signaling. J. Physiol. 499, 291-306.

Berridge, M. J. (1998). Neuronal calcium signaling. Neuron 21, 13-26.

Berridge, M. J. (2002). The endoplasmic reticulum: a multifunctional signaling organelle. Cell Calcium 32, 235-249.

Beutner, G., Sharma, V. K., Giovannucci, D. R., Yule, D. I., and Sheu, S. S. (2001). Identification of a ryanodine receptor in rat heart mitochondria. $J$. Biol. Chem. 276, 21482-21488.

Bezprozvanny, I. (2009). Calcium signaling and neurodegenerative diseases. Trends Mol. Med. 15, 89-100.

Bezprozvanny, I., and Mattson, M. P. (2008). Neuronal calcium mishandling and the pathogenesis of the late phase of long-term potentia-

\section{ACKNOWLEDGMENTS}

This research was entirely supported by the Intramural Research Program of the NIH, National Institute on Aging.

Alzheimer's disease. Trends Neurosci. 31, 454-463.

Bezprozvanny, I., Watras, J., and Ehrlich, B. E. (1991). Bell-shaped calciumresponse curves of Ins $(1,4,5) \mathrm{P} 3$ - and calcium-gated channels from endoplasmic reticulum of cerebellum. Nature 351, 751-754.

Billups, B., and Forsythe, I. D. (2002). Presynaptic mitochondrial calcium sequestration influences transmission at mammalian central synapses. J. Neurosci. 22, 5840-5847.

Bolshakov, V. Y., and Siegelbaum, S. A. (1994). Postsynaptic induction and presynaptic expression of hippocampal long-term depression. Science 264, 1148-1152.

Bootman, M. D., and Berridge, M. J. (1996). Subcellular Ca2 ${ }^{+}$signals underlying waves and graded responses in HeLa cells. Curr. Biol. 6, 855-865.

Bortolotto, Z. A., Clarke, V. R., Delany, C. M., Parry, M. C., Smolders, I., Vignes, M., Ho, K. H., Miu, P., Brinton, B. T., Fantaske, R., Ogden, A., Gates, M., Ornstein, P. L., Lodge, D., Bleakman, D., and Collingridge, G. L. (1999). Kainate receptors are involved in synaptic plasticity. Nature 402, 297-301.

Breuer, A. C., Bond, M., and Atkinson, M. B. (1992). Fast axonal transport is modulated by altering transaxolemmal calcium flux. Cell Calcium 13, 249-262.

Browne, L. E., Jiang, L. H., and North, R. A. (2010). New structure enlivens interest in P2X receptors. Trends Pharmacol. Sci. 31, 229-237.

Bullock, R., Graham, D. I., Swanson, S., and McCulloch, J. (1994). Neuroprotective effect of the AMPA receptor antagonist LY-293558 in focal cerebral ischemia in the cat. J. Cereb. Blood Flow Metab. 14, 466-471.

Burnstock, G., and Knight, G. E. (2004). Cellular distribution and functions of $\mathrm{P} 2$ receptor subtypes in different systems. Int. Rev. Cytol. 240, 31-304.

Cai, C., Lin, P., Cheung, K. H., Li, N., Levchook, C., Pan, Z., Ferrante, C., Boulianne, G. L., Foskett, J. K. Danielpour, D., and Ma, J. (2006). The presenilin-2 loop peptide perturbs intracellular $\mathrm{Ca}_{2}{ }^{+}$homeostasis and accelerates apoptosis. J. Biol. Chem. 281, 16649-16655.

Cain, S. M., and Snutch, T. P. (2010). Contribution of T-type calcium channels isoforms to neuronal firing. Channels 4, 475-482.
Cain, S. M., and Snutch, T. P. (2011). Voltage-gated calcium channels and disease. Biofactors 37, 197-205.

Campbell, L. W., Hao, S. Y., Thibault, O., Blalock, E. M., and Landfield, P. W. (1996). Aging changes in voltage-gated calcium currents in hippocampal CA1 neurons. J. Neurosci. 16, 6286-6295.

Campbell, S. L., Mathew, S. S., and Hablitz, J. J. (2007). Pre- and postsynaptic effects of kainate on layer II/III pyramidal cells in rat neocortex. Neuropharmacology 53, 37-47.

Carafoli, E. (1987). Intracellular calcium homeostasis. Annu. Rev. Biochem. 56, 395-433.

Carafoli, E., Tiozzo, R., Lugli, G., Crovetti, F., and Kratzing, C. (1974). The release of calcium from herat mitochondria by sodiun. J. Mol. Cell. Cardiol. 6, 361-371.

Castillo, P. E., Malenka, R. C., and Nicoll, R. A. (1997). Kainate receptors mediate a slow postsynaptic current in hippocampal CA3 neurons. Nature 388, 182-186.

Catterall, W. A. (2011). Voltage-gated calcium channels. Cold. Spring. Harb. Perspect. Biol. 3, a003947.

Catterall, W. A., and Few, A. P. (2008). Calcium channel regulation and presynaptic plasticity. Neuron 59, 882-901.

Catterall, W. A., Perez-Reyes, E. Snutch, T. P., and Striessnig, J. (2005). Nomenclature and structure-function relationships of voltage-gated calcium channels. Pharmacol. Rev. 57, 411-425.

Cavus, I., and Teyler, T. (1996). Two forms of long-term potentiation in area CAl activate different signal transduction cascades. J. Neurophysiol. 76, 3038-3047.

Chan, C. S., Guzman, J. N., Ilijic, E., Mercer, J. N., Rick, C., Tkatch, T., Meredith, G. E., and Surmeier, D. J. (2007). 'Rejuvenation' protects neurons in mouse models of Parkinson's disease. Nature 447, 1081-1086.

Chan, S. L., Mayne, M., Holden, C. P., Geiger, J. D., and Mattson, M. P. (2000). Presenilin-1 mutations increase levels of ryanodine receptors and calcium release in PC12 cells and cortical neurons. J. Biol. Chem. 275, 18195-18200.

Chang, C. S., Gertler, T. S., and Sumeier, D. J. (2009). Calcium homeostasis, selective vulnerability and Parkinson's disease. Trends Neurosci. 32, 249-256. 
Charvin, N., L'Evêque, C., Walker, D., Berton, F., Raymond, C., Kataoka, M., Shoji-Kasai, Y., Takahashi, M., De Waard, M., and Seagar, M. J. (1997). Direct interaction of the calcium sensor protein synaptotagmin I with a cytoplasmic domain of the alpha1A subunit of the P/Qtype calcium channel. $E M B O \mathrm{~J} .16$, 4591-4596.

Chavis, P., Fagni, L., Lansman, J. B., and Bockaert, J. (1996). Functional coupling between ryanodine receptors and L-type calcium channels in neurons. Nature 382, 719-722.

Chawla, S., Hardingham, G. E, Quinn, D. R., and Bading, H. (1998). CBP: a signal-regulated transcriptional coactivator controlled by nuclear calcium and CaM kinase IV. Science 281, 1505-1509.

Cheung, K. H., Shineman, D., Müller, M., Cárdenas, C., Mei, L., Yang, J., Tomita, T., Iwatsubo, T., Lee, V. M., and Foskett, J. K. (2008). Mechanism of $\mathrm{Ca}_{2}{ }^{+}$disruption in Alzheimer's disease by presenilin regulation of InsP3 receptor channel gating. $\mathrm{Neu}-$ ron 58, 871-883.

Chittajallu, R., Braithwaite, S. P., Clarke, V. R., and Henley, J. M. (1999). Kainate receptors: subunits, synaptic localization and function. Trends Pharmacol. Sci. 20, 26-35.

Chohan, M. O., and Iqbal, K. (2006). From tau to toxicity: emerging roles of NMDA receptor in Alzheimer's disease. J. Alzheimers Dis. 10, 81-87.

Choi, D. W. (1990). Possible mechanisms limiting N-methyl-Daspartate receptor overactivation and the therapeutic efficacy of $\mathrm{N}$-methyl-D-aspartate antagonists. Stroke 21(Suppl. 11), III20-III22.

Christie, B. R., Magee, J. C., and Johnston, D. (1996). Dendritic calcium channels and hippocampal longterm depression. Hippocampus 6, 17-23.

Chrivia, J. C., Kwok, R. P., Lamb, N., Hagiwara, M., Montminy, M. R., and Goodman, R. H. (1993). Phosphorylated CREB binds specifically to the nuclear protein CBP. Nature 365 , 855-859.

Clarke, V. R., Ballyk, B. A., Hoo, K. H., Mandelzys, A., Pellizzari, A., Bath, C. P., Thomas, J., Sharpe, E. F., Davies, C. H., Ornstein, P. L., Schoepp, D. D., Kamboj, R. K., Collingridge, G. L., Lodge, D., and Bleakman, D. (1997). A hippocampal GluR5 kainate receptor regulating inhibitory synaptic transmission. Nature 389, 599-603.

Collingridge, G. L., Olsen, R. W., Peters, J., and Spedding, M. (2009). A nomenclature for ligand-gated ion channels. Neuropharmacology 56, 2-5.

Contractor, A., Mulle, C., and Swanson, T. G. (2011). Kainate receptors coming of age: milestones of two decades of research. Trends Neurosci. 34, 154-163.

Contractor, A., Swanson, G., and Heinemann, S. F. (2001). Kainate receptors are involved in short- and long-term plasticity at mossy fiber synapses in the hippocampus. Neuron 29, 209-216.

Contractor, A., Swanson, G. T., Sailer, A., O'Gorman, S., and Heinemann, S. F. (2000). Identification of the kainite receptor subunits underlying modulation of excitatory synaptic transmission in the $\mathrm{CA} 3$ region of the hippocampus. J. Neurosci. 20 8269-8278.

Coon, A. L., Wallace, D. R., Mactutus, C. F., and Booze, R. M. (1999). L-type calcium channels in the hippocampus and cerebellum of Alzheimer's disease brain tissue. Neurobiol. Aging 20, 597-603.

Cossart, R., Tyzio, R., Dinocourt, C., Esclapez, M., Hirsch, J. C., Ben-Ari, Y., and Bernard, C. (2001). Presynaptic kainite receptors that enhance the release of GABA on CA1 hippocampal interneurons. Neuron 29 , 497-508.

Crunelli, V., Cope, D. W., and Hughes, S. W. (2006). Thalamic T-type $\mathrm{Ca}^{2+}$ channels and NREM sleep. Cell Calcium 40, 175-190.

Csordás, G., Renken, C., Várnai, P., Walter, L., Weaver, D., Buttle, K. F., Balla, T., Mannella, C. A., and Hajnóczky, G. (2006). Structural and functional features and significance of the physical linkage between ER and mitochondria. J. Cell Biol. 174, 915-921.

Dajas-Bailador, F. A., Mogg, A. J., and Wonnacott, S. (2002). Intracellular $\mathrm{Ca}^{2+}$ signals evoked by stimulation of nicotinic acetylcholine receptors in SH-SY5Y cells: contribution of voltage-operated $\mathrm{Ca}^{2+}$ channels and $\mathrm{Ca}^{2+}$ stores. J. Neurochem. 81, 606-614.

Dani, J. A., and Bertrand, D. (2007) Nicotinic acetylcholine receptors and nicotinic cholinergic mechanisms of the central nervous system. Annu. Rev. Pharmacol. Toxicol. 47 699-729.

Davare, M. A., and Hell, J. W. (2003). Increased phosphorylation of the neuronal L-type $\mathrm{Ca}(2+)$ channel $\mathrm{Ca}(\mathrm{v}) 1.2$ during aging. Proc. Natl. Acad. Sci. U.S.A. 100, 16018-16023.

Davare, M. A, Avdonin, V., Hall, D. D, Peden, E. M., Burette, A., Weinberg, R. J., Horne, M. C., Hoshi, T., and Hell, J. W. (2001). A beta 2 adrenergic receptor signaling complex assembled with the $\mathrm{Ca}^{2+}$ channel $\mathrm{Ca}_{\mathrm{v}} 1.2$. Science 293, 98-101.

David, G., and Barrett, E. F. (2000) Stimulation-evoked increases in cytosolic $[\mathrm{Ca}(2+)]$ in mouse motor nerve terminals are limited by mitochondrial uptake and are temperature-dependent. J. Neurosci. 20, 7290-7296.

David, G., and Barrett, E. F. (2003). Mitochondrial $\mathrm{Ca}^{2+}$ uptake prevents desynchronization of quantal release and minimizes depletion during repetitive stimulation of mouse motor nerve terminals. $J$. Physiol. (Lond.) 548, 425-438.

Davies, P. A., Pistis, M., Hanna, M. C., Peters, J. A., Lambert, J. J., Hales, T. G., and Kirkness, E. F. (1999). The 5-HT3B subunit is a major determinant of serotonin receptor function. Nature 397, 359-363.

Day, N. C., Shaw, P. J., McCormack, A. L., Craig, P. J., Smith, W., Beattie, R., Williams, T. L., Ellis, S B., Ince, P. G, Harpold, M. M. Lodge, D., and Volsen, S. G. (1996). Distribution of alpha $1 \mathrm{~A}$, alpha $1 \mathrm{~B}$ and alpha $1 \mathrm{E}$ voltage-dependent calcium channel subunits in the human hippocampus and parahippocampal gyrus. Neuroscience 71 , 1013-1024.

de Brito, O. M., and Scorrano, L. (2009). Mitofusin-2 regulates mitochondrial and endoplasmic reticulum morphology and tethering: the role of Ras. Mitochondrion 9, 222-226.

de Brito, O. M., and Scorrano, L. (2010). An intimate liaison: spatial organization of the endoplasmic reticulummitochondria relationship. $E M B O J$ 29, 2715-2723.

De Stefani, D., Raffaello, A., Teardo, E., Szabò, I., Rizzuto, R. (2011). A forty-kilodalton protein of the inner membrane is the mitochondrial calcium uniporter. Nature 476, 336-340.

De Strooper, B., and Annaert, W. (2010). Novel research horizons for presenilins and g-secretases in cell biology and disease. Annu. Rev. Cell Dev. Biol. 26, 235-260.

De Strooper, B., Saftig, P., Craessaerts, K., Vanderstichele, H., Guhde, G., Annaert, W., Von Figura, K., and Van Leuven, F. (1998). Deficiency of presenilin-1 inhibits the normal cleavage of amyloid precursor protein. Nature 391, 387-390.

De Waard, M., Liu, H. Y., Walker, D., Scott, V. E. S., Gurnett, C. A. and Campbell, K. P. (1997). Direct binding of G-protein $\beta \gamma$ complex to voltage-dependent calcium channels. Nature 385, 446-450.
Deisseroth, K., Heist, E. K., and Tsien, R. W. (1998). Translocation of calmodulin to the nucleus supports CREB phosphorylation in hippocampal neurons. Nature 392, 198-202.

Delmas, P., Abogadie, F. C., Buckley, N. J., and Brown, D. A. (2000) Calcium channel gating and modulation by transmitters depend on cellular compartmentalization. Nat. Neurosci. 3, 670-678.

Delorme, R., Krebs, M. O., Chabane, N., Roy, I., Millet, B., Mouren-Simeoni, M. C., Maier, W., Bourgeron, T., and Leboyer, M. (2004). Frequency and transmission of glutamate receptors GRIK2 and GRIK3 polymorphisms in patients with obsessive compulsive disorder. Neuroreport 15, 699-702.

Deluca, H. F., and Engstrom, G. W. (1961). Calcium uptake by rat kidney mitochondria. Proc. Natl. Acad. Sci. U.S.A. 47, 1744-1750.

Denton, R. M., McCormack, J. G., and Edgell, N. J. (1980). Role of calcium ions in the regulation of intramitochondrial metabolism. Effects of $\mathrm{Na}+, \mathrm{Mg} 2+$ and ruthenium red on the $\mathrm{Ca}^{2+}$-stimulated oxidation of oxoglutarate and on pyruvate dehydrogenase activity in intact rat heart mitochondria. Biochem. J. 190 107-117.

Deyo, R. A., Straube, K. T., and Disterhoft, J. F. (1989). Nimodipine facilitates associative learning in aging rabbits. Science 243, 809-811.

Dietrich, D., Kirschtein, T., Kukley, M., Pereverzev, A., von der Brelie, C., Schneider, T., and Beck, H. (2003). Functional specialization of presynaptic $\mathrm{Ca}_{\mathrm{v}} 2.3 \mathrm{Ca}^{2+}$ channels. Neuron 39, 483-496.

Dingledine, R., Borges, K., Bowie, D., and Traynelis, S. F. (1999). The glutamate receptor ion channels. Pharmacol. Rev. 51, 7-61.

Disterhoft, J. F., Moyer, J. R., and Thompson, L. T. (1994). The calcium rationale in aging and Alzheimer's disease. Evidence from an animal model of normal aging. Ann. N. Y. Acad. Sci. 747, 382-406.

Disterhoft, J. F., and Oh, M. M. (2006). Pharmacological and molecular enhancement of learning in aging and Alzheimer's disease. J. Physiol. Paris 99, 180-192.

Dolmetsch, R. (2003). Excitationtranscription coupling: signaling by ion channels to the nucleus. Sci. STKE 3, PE4

Dubin, A. E., Huvar, R., D’Andrea, M. R., Pyati, J., Zju, J. Y., Joy, K. C., Wilson, S. J., Galindo, J. E., Glass, C. A., Luo, L., Jackson, M. R., Lovenberg, T. W., and Erlander, M. G. (1999). 
The pharmacological and functional characteristics of the serotonin 5HT3 receptor are specifically modified by a 5-HT3B receptor subunit. J. Biol. Chem. 274, 30799-30810.

Dunlap, K., Luebke, J. I., and Turner, T. J. (1995). Exocitotic $\mathrm{Ca}^{2+}$ channels in mammalian central neurons. Trends Neurosci. 18, 89-98.

Egebjerg, J., and Heinemann, S. F. (1993). $\mathrm{Ca}^{2+}$ permeability of unedited and edited versions of the kainate selective glutamate receptor GluR6. Proc. Natl. Acad. Sci. U.S.A. 90, 755-759.

Emptage, N. J., Reid, C. A., and Fine, A. (2001). Calcium stores in hippocampal synaptic boutons mediate short-term plasticity, store- operated $\mathrm{Ca}^{2+}$ entry, and spontaneous transmitter release. Neuron 29, 197-208.

Engleman, E. A., Rodd, Z. A., Bell, R. L., and Murphy, J. M. (2008). The role of 5-HT3 receptors in drug abuse and as a target for pharmacotherapy. CNS Neurol. Disord. Drug Targets 7, 454-467.

Fan, M. M., and Raymond, L. A. (2007). N-methyl-D-aspartate (NMDA) receptor function and excitotoxicity in Huntington's disease. Prog. Neurobiol. 81, 272-293.

Färber, L., Haus, U., Späth, M., and Drechsler, S. (2004). Physiology and pathophysiology of the 5-HT3 receptor. Scand. J. Rheumatol. Suppl. 119, 2-8.

Finch, E. A., Turner, T. J., and Goldin, S. M. (1991). Calcium as a coagonist of inositol 1,4,5-trisphospahteinduced calcium release. Science 252, 443-446.

Finkbeiner, S., and Greenberg, M. E. (1996). $\mathrm{Ca}^{2+}$-dependent routes to ras: mechanisms for neuronal survival, differentiation, and plasticity? Neuron 16, 233-236.

Florczyk, A. P., Schurig, J. E., and Bradner, W. T. (1982). Cisplatin-induced emesis in the ferret. A new animal model. Cancer Treat. Rep. 66, 187-189.

Floyd, R. A., and Hensley, K. (2002). Oxidative stress in brain aging. Implications for therapeutics of neurodegenerative diseases. Neurobiol. Aging 23, 795-807.

Forette, F., Seux, M. L., Staessen, J. A., Thijs, L., Babarskiene, M. R., Babeanu, S., Bossini, A., Fagard, R., Gil-Extremera, B., Laks, T., Kobalava, Z., Sarti, C., Tuomilehto, J., Vanhanen, H., Webster, J., Yodfat, Y., and Birkenhager, W. H. (2002). The prevention of dementia with antihypertensive treatment: new evidence from the systolic hypertension in Europe (Syst-Eur) study, Arch. Intern. Med. 162, 2046-2052.

Foskett, J. K., White, C., Cheung, K. H., and Mak, D. O. (2007). Inositol trisphosphate receptor $\mathrm{Ca}^{2+}$ release channels. Physiol. Rev. 87, 593-658.

Foster, T. C. (2006). Biological markers of age-related memory deficits: treatment of senescent physiology. CNS Drugs 20, 153-166.

Foster, T. C., Sharrow, K. M., Messe, J. R., Norrris, C. M., and Kumar, A. (2001). Calcineurin links $\mathrm{Ca}^{2+}$ dysregulation with brain aging. $J$. Neurosci. 21, 4066-4073.

Fozard, J. R., and Mobarok, A. A. (1978). Blockade of neuronal tryptamine receptors by metoclopramide. Eur. J. Pharmacol. 49, 109-112.

Frerking, M., and Ohlinger-Frerking, P. (2002). AMPA receptors and kainite receptors encode different features of afferent activity. J. Neurosci. 22, 7434-7443.

Frerking, M., Schmitz, D., Zhou, Q., Johansen, J., and Nicoll, R. A. (2001). Kainate receptors depress excitatory synaptic transmission at CA3->CA1 synapses in the hippocampus via a direct presynaptic action. J. Neurosci. 21, 2958-2966.

Fucile, S. (2004). $\mathrm{Ca}^{2+}$ permeability of nicotinic acetylcholine receptors. Cell Calcium 35, 1-8.

Fujii, S., Matsumoto, M., Igarashi, K., Kato, H., and Mikoshiba, K. (2000). Synaptic plasticity in hippocampal CA1 neurons of mice lacking type 1 inositol-1,4,5-trisphosphate receptors. Learn. Mem. 7, 312-320.

Furuichi, T., Furutama, D., Hakamata, Y., Nakai, J., Takeshima, H., and Mikoshiba, K. (1994). Multiple types of ryanodine receptor/ $/ \mathrm{Ca}^{2+}$ release channels are differentially expressed in rabbit brain. J. Neurosci. 14, 4794-4805.

Futatsugi, A., Kato, K., Ogura, H., Li, S. T., Nagata, E., Kuwajima, G., Tanaka, K., Itohara, S., and Mikoshiba, K. (1999). Facilitation of NMDARindependent LTP and spatial learning in mutant mice lacking ryanodine receptor type 3 . Neuron 24 , 701-173.

Gallagher, M., Landfield, P. W., McEwen, B., Meaney, M. J., Rapp, P. R., Sapolsky, R., and West, M. J. (1996). Hippocampal neurodegeneration in aging. Science 25, 484-485.

Gant, J. C., Sama, M. M., Landfield, P. W., and Thibault, O. (2006). Early and simultaneous emergence of multiple hippocampal biomarkers of aging is mediated by $\mathrm{Ca}^{2+}$ induced $\mathrm{Ca}^{2+}$ release. J. Neurosci. 26, 3482-3490.
Gao, J., Yin, D., Yao, Y., Williams, T. D., and Squier, T. C. (1998). Progressive decline in the ability of calmodulin isolated from aged brain to activate the plasma membrane Ca-ATPase. Biochemistry 37, 9536-9548.

Gibson, G. E., and Peterson, C. (1987). Calcium and the aging nervous system. Neurobiol. Aging 8, 329-343.

Gill, R., and Lodge, D. (1994). The neuroprotective effects of the decahydroisoquinoline, LY215490; a novel AMPA antagonist in focal ischemia. Neuropharmacology 33 1529-1536.

Green, D. R., and Kroemer, G. (2004). The pathophysiology of mitochondrial cell death. Science 305, 626-629.

Green, E. M, Barrett, C. F., Bultynck, G., Shamah, S. M., and Dolmetsch, R. E. (2007). The tumor suppressor eIF3e mediates calcium-dependent internalization of the L-type calcium channel Cav1.2. Neuron 55, 615-632.

Green, K. N., Demuro, A., Akbari, Y., Hitt, B. D., Smith, I. F., parker, I., and LaFerla, F. M. (2008). SERCA pump activity is physiologically regulated by presenilin and regulates amyloid beta production. J. Cell Biol. 181, 1107-1116.

Grover, L. M., and Teyler, T. J (1990). Two components of longterm potentiation induced by different patterns of afferent activation. Nature 347, 477-479.

Gu, J. G., Albuquerque, C., Lee, C. J., and MacDermott, A. B. (1996). Synaptic strengthening through activation of $\mathrm{Ca}^{2+}$-permeable AMPA receptors. Nature 381, 793-796.

Guo, Q., Fu, W., Sopher, B. L., Miller, M. W., Ware, C. B., Martin, G. M., and Mattson, M. P. (1999). Increased vulnerability in hippocampal neurons to excitotoxic necrosis in presenilin1 mutant knock-in mice. Nat. Med. 5, 101-106.

Guo, Q., Furukawa, K., Sopher, B. L. Pham, D. G., Xie, J., Robinson, N., Martin, G. M., and Mattson, M. P. (1996). Alzheimer's PS-1 mutation perturbs calcium homeostasis and sensitizes PC12 cells to death induced by amyloid beta-peptide. Neuroreport 8, 379-383.

Hakamata, Y., Nakai, J., Takeshima, H., and Imoto, K. (1992). Primary structure and distribution of a novel ryanodine receptor/calcium release channel from rabbit brain. FEBS Lett. 312, 229-235.

Halestrap, A. P. (2009). What is the mitochondrial permeability transition pore? J. Mol. Cell. Cardiol. 46, 821-831.
Hansford, R. G. (1980). Control of mitochondrial substrate oxidation. Curr. Top. Bioenerg. 10, 217-278.

Hardingham, G. E., Arnold, F. J., and Bading, H. (2001a). Calcium microdomain near NMDA receptors: on-switch of ERKdependent synapse-to-nucleus communication. Nat. Neurosci. 4, 565-566.

Hardingham, G. E., Arnold, F. J., and Bading, H. (2001b). Nuclear calcium signaling controls CREBmediated gene expression triggered by synaptic activity. Nat. Neurosci. 4 , 261-267.

Hardingham, G. E., and Bading, $\mathrm{H}$. (2010). Synaptic versus extrasynaptic NMDA receptor signaling: implications for neurodegenerative disorders. Nat. Rev. Neurosci. 11, 682-696.

Hardingham, G. E., Chawla, S., Cruzalegui, F. H., and Bading, $H$. (1999). Control of recruitment and transcription-activating function of CBP determines gene regulation by NMDA receptors and Ltype calcium channels. Neuron 22, 789-798.

Hargreaves, A. C., Lummis, S. C. R., and Taylor, C. W. (1994). $\mathrm{Ca}^{2+}$ permeability of cloned and native 5hydroxytryptamine type 3 receptors. Mol. Pharmacol. 46, 1120-1128.

Hayashi, T., Martone, M. E., Yu, Z., Thor, A., Doi, M., Holst, M. J., Elismam, M. H., and Hoshijima, M. (2009). Three-dimensional electron microscopy reveals new details of membrane systems for $\mathrm{Ca}^{2+}$ signaling in the heart. J. Cell. Sci. 122 , 1005-1013.

Hayashi, T., and Su, T. P. (2007). Sigma-1 receptor chaperones at the ER-mitochondrion interface regulate $\mathrm{Ca}^{2+}$ signaling and cell survival. Cell 131, 596-610.

Hayrapetyan, V., Jenschke, M., Dillon, G. H., and Machu, T. K. (2005). Coexpression of the 5-HT(3B) subunit with the 5-HT(3A) receptor reduces alcohol sensitivity. Brain Res. Mol. Brain Res. 142, 146-150.

Hell, J. W., Westenbroek, R. E., Warner, C., Ahlijanian, M. K., Prystay, W., Gilbert, M. M., Snutch, T. P., and Catterall, W. A. (1993). Identification and differential subcellular localization of the neuronal class $\mathrm{C}$ and class D L-type calcium channel alpha 1 subunits. J. Cell Biol. 123, 949-962.

Henkart, M. P., Reese, T. S., and Brinley, F. J. Jr. (1978). Endoplasmic reticulum sequesters calcium in the squid giant axon. Science 202, 1300-1303. 
Herb, A., Burnashev, N., Werner, P., Sakmann, B., Wisden, W., and Seeburg, P. H. (1992). The KA-2 subunit of excitatory amino acid receptors shows widespread expression in brain and forms ion channels with distantly related subunits. Neuron 8 , 775-785.

Herlitze, S., Garcia, D. E., Mackie, K., Hille, B., Scheuer, T., and Catterall, W.A. (1996). Modulation of calcium channels by $G$ protein $\beta \gamma$ subunits. Nature 380, 258-262.

Herman, J. P., Chen, K. C., Booze, R., and Landfield, P. W. (1998). Upregulation of alpha1D $\mathrm{Ca}^{2+}$ channel subunit mRNA expression in the hippocampus of aged F344 rats. Neurobiol. Aging 19, 581-587.

Heron, S. E., Phillips, H. A., Mulley, J. C., Mazarib, A., Neufeld, M. Y., Berkovic, S. F., and Scheffer, I. E. (2004). Genetic variation of CACNA1H in idiopatic generalized epilepsy. Ann. Neurol. 55, 595-596.

Higo, T., Hattori, M., Nakamura, T., Natsume, T., Michikawa, T., and Mikoshiba, K. (2005). Subtype specific and Er luminal environmentaldependent regulation of inositol 1,4,5-trisphosphate receptor type 1 by ERp44. Cell 120, 85-98.

Hollmann, M., and Heinemann, S. (1994). Cloned glutamate receptors. Annu. Rev. Neurosci. 17, 31-108.

Hollmann, M., Maron, C., and Heinemann, S. (1994). N-glycosylation site taggin suggest a three transmembrane domain topology for the glutamate receptor GluR1. Neuron 13, 1331-1343.

Huettner, J. E. (2003). Kainate receptors and synaptic transmission. Prog. Neurobiol. 70, 387-407.

Huguenard, J. R. (1996). Low-threshold calcium channels currents in central nervous system neurons. Annu. Rev. Physiol. 58, 329-348.

Impey, S., Fong, A. L., Wang, Y., Cardinaux, J. R., Fass, D. M., Obrietan, K., Wayman, G. A., Storm, D. R., Soderling, T. R., and Goodman, R. H. (2002). Phosphorylation of CBP mediates transcriptional activation by neural activity and CaM kinase IV. Neuron 34, 235-244.

Impey, S., and Goodman, R. H. (2001). CREB signaling-timing is everything. Sci. STKE 82, pe1.

Impey, S., Mark, M., Villacres, E. C., Poser, S., Chavkin, C., and Storm, D. R. (1996). Induction of CREmediated gene expression by stimuli that generate long-lasting LTP in area CAl of the hippocampus. Neuron 16, 973-982.

Ingram, D. K., Joseph, J. A., Spangler, E. L., Roberts, D., Hengemihle, J., and Fanelli, R. J. (1994). Chronic nimodipine treatment in aged rats: analysis of motor and cognitive effects and muscarinic-induced striatal dopamine release. Neurobiol. Aging 15, 55-61.

Inoue, T., Kato, K., Kohda, K., and Mikoshiba, K. (1998). Type 1 inositol 1,4,5-trisphosphate receptor is required for induction of long-term depression in cerebellar Purkinje neurons. J. Neurosci. 18, 5366-5373.

Isaac, J. T., Ashby, M. C., and McBain, C. J. (2007). The role of the GluR2 subunit in AMPA receptor function and synaptic plasticity. Neuron 54, 859-871.

Ito, E., Oka, K., Etcheberrigaray, R., Nelson, T. J., McPhie, D. L., Tofel-Grehl, B., Gibson, G. E., and Alkon, D. L. (1994). Internal $\mathrm{Ca}^{2+}$ mobilization is altered in fibroblasts from patients with Alzheimer disease. Proc. Natl. Acad. Sci. U.S.A. 91, 534-538.

Iwai, M., Tateishi, Y., Hattori, M., Mizutani, A., Nakamura, T., Futatsugi, A., Inoue, T., Furuichi, T., Michikawa, T., and Mikoshiba, K. (2005). Molecular cloning of mouse type 2 and type 3 inositol 1,4,5-trisphosphate receptors and identification of a novel type 2 receptor splice variant. J. Biol. Chem. 280, 10305-10317.

Jia, Z., Agopyan, N., Miu, P., Xiong, Z., Henderson, J., Gerlai, R., Taverna, F. A., Velumian, A., MacDonald, J., Carlen, P., Abramow-Newerly, W., and Roder, J. (1996). Enhanced LTP in mice deficient in the AMPA receptor GluR2. Neuron 17, 945-56.

Jiang, D., Zhao, L., and Clapham, D. E. (2009). Genome-wide RNAi screen identifies Letm 1 as a mitochondrial $\mathrm{Ca}^{2+} / \mathrm{H}+$ antiporter. Science 326, 144-147.

Jiang, L., Xu, J., Nedergaard, M., and Kang, J. (2001). A kainite receptor increases the efficacy of GABAergic synapses. Neuron 30, 503-513.

Jin, X. T., Pare, J. F., Raju, D. V., and Smith, Y. (2006) Localization and function of pre- and postsynaptic kainite receptors in the rat globus pallidus. Eur. J. Neurosci. 23, 374-386.

Jouaville, 1. S., Pinton, P., Bastianutto, C., Rutter, G. A., and Rizzuto, R. (1999). Regulation of mitochondrial ATP synthesis by calcium: evidence for long-term metabolic priming. Proc. Natl. Acad. Sci. U.S.A. 96, 13807-13812.

Kamiya, H., and Ozawa, S. (1998). Kainate receptor-mediated inhibition of presynaptic $\mathrm{Ca} 2+$ influx and EPSP in area CA1 of the rat hippocampus. J. Physiol. (Lond.) 509, 833-845.
Kamiya, H., and Ozawa, S. (2000). Kainate receptor-mediated presynaptic inhibition at the mouse hippocampal mossy fibre synapse. $J$. Physiol. (Lond.) 523, 653-665.

Kawai, T., and Watanabe, M. (1989). Effects of ryanodine on the spike after-hyperpolarization in sympathetic neurones of the rat superior cervical ganglion. Pflugers Arch. 413, 470-475.

Khachaturian, Z. S. (1989). Calcium, membranes, aging, and Alzheimer's disease. Introduction and overview. Ann. N. Y. Acad. Sci. 568, 1-4.

Khachaturian, Z. S. (1994). Calcium hypothesis of Alzheimer's disease and brain aging. Ann. N. Y. Acad. Sci. 747, 1-11.

Kilpatrick, G. J., Jones, B. J., and Tyers, M. B. (1987). Identification and distribution of 5-HT3 receptor, a serotonin-gated ion channel. Nature 330, 746-748.

Ko, S., Zhao, M. G., Toyoda, H. Qiu, C. S., and Zhuo, M. (2005). Altered behavioral responses to noxious stimuli and fear in glutamate receptor 5 (GluR5)- or GluR6deficient mice. J. Neurosci. 25, 977-984.

Kohda, K., Inoue, T., and Mikoshiba, K. (1995). $\mathrm{Ca}^{2+}$ release from $\mathrm{Ca}^{2+}$ stores, particularly from ryanodinesensitive $\mathrm{Ca}^{2+}$ stores, is required for the induction of LTD in cultured cerebellar Purkinje cells. J. Neurophysiol. 74, 2184-2188.

Kohler, M., Burnashev, N., Sakmann, B. and Seeburg, P. H. (1993). Determinants of $\mathrm{Ca} 2+$ permeability in both TM1 and TM2 of high affinity kainate receptor channels: diversity by RNA editing. Neuron 10, 491-500.

Korenkov, A. I., Pahnke, J., Frei, K., Warzok, R., Schroeder, H. W., Frick, R., Muljana, L., Piek, J., Yonekawa, Y., and Gaab, M. R. (2000). Treatment with nimodipine or mannitol reduces programmed cell death and infarct size following focal cerebral ischemia. Neurosurg. Rev. 23, 145-150.

Kouzu, Y., Moriya, T., Takeshima, H., Yoshioka, T., and Shibata, S. (2000). Mutant mice lacking ryanodine receptor type 3 exhibit deficits of contextual fear conditioning and activation of calcium/calmodulindependent protein kinase II in the hippocampus. Brain Res. Mol. Brain Res. 76, 142-150.

Kowalska, M., and Disterhoft, J. F. (1994). Relation of nimodipine dose and serum concentration to learning enhancement in aging rabbits. Exp. Neurol. 127, 159-166.
Koyama, S., Matsumoto, N., Kubo, C., and Akaike, N. (2000). Presynaptic $5-\mathrm{HT}_{3}$ receptor-mediated modulation of synaptic GABA release in the mechanically dissociated rat amygdala neurons. J. Physiol. (Lond.) 529, 373-383.

Kullmann, D. M., and Lamsa, K. P. (2007). Long-term synaptic plasticity in hippocampal interneurons. Nat. Rev. Neurosci. 8, 687-699.

Kumar, A., and Foster, T. C. (2004). Enhanced long-term potentiation during aging is masked by processes involving intracellular calcium stores. J. Neurophysiol. 91, 2437-2444.

Kumar, A., and Foster, T. C. (2005) Intracellular calcium stores contribute to increased susceptibility to LTD induction during aging. Brain Res. 1031, 125-128.

Kutsuwada, T., Kashiwabuchi, N., Mori, H., Sakimura, K., Kushiya, E., Araki, K., Meguro, H., Masaki, H., Kumanishi, T., Arakawa, M., and Mishina, M. (1992). Molecular diversity of NMDA receptor channel. Nature 358, 36-41.

Lancelot, E., and Beal, M. F. (1998). Glutamate toxicity in chronic neurodegenerative disease. Prog. Brain Res. 116, 331-347.

Landfield, P. W., and Pitler, T. A. (1984). Prolonged $\mathrm{Ca}^{2+}$-dependent afterhyperpolarizations in hippocampal neurons of aged rats. Science 226, 1089-1092.

Lauri, S. E., Bortolotto, Z. A., Nistico, R., Bleakman, D., Orstein, P. L., Lodge, D., Isaac, J. T., and Collidridge, G. L. (2003). A role for $\mathrm{Ca} 2+$ stores in kainite receptordependent synaptic facilitation and LTP at mossy fiber synapses in the hippocampus. Neuron 39, 327-341.

Lauri, S. E., Segerstrale, M., Vesikansa, A., Maingret, F., Mulle, C., Collingridge, G. L., Isaac, J. T., and Taira, T. (2005). Endogenous activation of kainite receptors regulates glutamate release and network activity in the developing hippocampus. J. Neurosci. 25, 4473-4484.

Lauri, S. E., and Taira, T. (2011). Role of kainite receptors in network activity during development. Adv. Exp. Med. Biol. 717, 81-91.

Lauri, S. E., Vesikansa, A., Segerstrale, M., Collingridge, G. L., Isaac, J. T., and Taira, T. (2006). Functional maturation of CA1 synapses involves activity-dependent loss of tonic kainite receptor-mediated inhibition of glutamate release. Neuron 50, 415-429. 
Laver, D. R. (2007). Ca ${ }^{2+}$ stores regulate ryanodine receptor $\mathrm{Ca}^{2+}$ release channels via luminal and cytosolic $\mathrm{Ca}^{2+}$ sites. Clin. Exp. Pharmacol. Physiol. 34, 889-896.

Lee, A. C., Xu, X., Blachly-Dyson, E., Forte, M., and Colombini, M. (1998). The role of yeast VDAC genes on the permeability of the mitochondrial outer membrane. $J$. Membr. Biol. 161, 173-181.

Lee, H. K., and Kirkwood, A. (2011). AMPA receptor regulation during synaptic plasticity in hippocampus and neocortex. Semin. Cell Dev. Biol. $22,514-520$

Lee, H. K., Min, S. S., Gallagher, M., and Kirkwood, A. (2005). NMDA receptor-independent longterm depression correlates with successful aging in rats. Nat. Neurosci. 8, 1657-1659.

Lee, S. J., Escobedo-Lozoya, Y., Szatmari, E. M., and Yasuda, R. (2009). Activation of CaMKII in single dendritic spines during long-term potentiation. Nature 458, 299-304

Leissring, M. A., Akbari, Y., Fanger, C. M., Cahalan, M. D., Mattson, M. P., and LaFerla, F. M. (2000). Capacitative calcium entry deficits and elevated luminal calcium content in mutant presenilin-1 knockin mice. J. Cell Biol. 149, 793-798.

Leissring, M. A., Parker, I., and LaFerla, F. M. (1999a). Presenilin-2 mutations modulate amplitude and kinetics of inositol 1,4,5-trisphosphatemediated calcium signals. J. Biol. Chem. 274, 32535-32538.

Leissring, M. A., Paul, B. A., Parker, I., Cotman, C. W., and LaFerla, F. M. (1999b). Alzheimer's presenilin-1 potentiates inositol 1,4,5-trisphosphate-mediated calcium signaling in Xenopus oocytes. J. Neurochem. 72, 1061-1068.

Lerma, J. (2006). Kainate receptors physiology. Curr. Opin. Pharmacol. 6, 89-97.

Leung, A. W., and Halestrap, A. P. (2008). Recent progress in elucidating the molecular mechanism of the mitochondrial permeability transition. Biochim. Biophys. Acta 1777, 946-952.

Levere, T. E., and Walker, A. (1992). Old age and cognition: enhancement of recent memory in aged rats by the calcium channel blocker nimodipine. Neurobiol. Aging 13, 63-66.

Levin, E. D., and Simon, B. B. (1998). Nicotinic acetylcholine involvement in cognitive function in animals. Psychopharmacology (Berl.) 138, 217-230.

Levy-Lahad, E., Wijsman, E. M., Nemens, E., Anderson, L., Goddard,
K. A., Weber, J. L., Bird, T. D., and Schellenberg, G. D. (1995). A familial Alzheimer's disease locus on chromosome 1. Science 269, 970-973.

Li, B., Zhong, H., Scheuer, T., and Catterall, W. A. (2004). Functional role of a C-terminal $\mathrm{G} \beta \gamma$-binding domain of $\mathrm{Ca}_{\mathrm{v}} 2.2$ channels. Mol. Pharmacol. 66, 761-769.

Lin, M. T., and Beal, M. F. (2006). Mitochondrial dysfunction and oxidative stress in neurodegenerative diseases. Nature 443, 787-795.

Liu, J., and Zukin, R. S. (2007). $\mathrm{Ca}^{2+}$-permeable AMPA receptors in synaptic plasticity and neuronal death. Trends Neurosci. 30, 126-134.

Liu, P., Smith, P. F., and Darlington, C. L. (2008). Glutamate receptor subunits expression in memory-associated brain structures: regional variations and effects of aging. Synapse 62, 834-841.

Llinas, R. R. (1988). The intrinsic electrophysiological properties of mammalian neurons: insights into central nervous system function. Science 242, 1654-1664.

Lohmann, C., and Wong, R. O. (2005). Regulation of dendritic growth and plasticity by local and global calcium dynamics. Cell Calcium 37, 403-409.

Ma, H., Cai, Q., Lu, W., Sheng, Z. H., and Mochida, S. (2009). KIF5B motor adaptor syntabulin maintains synaptic transmission in sympathetic neurons. J. Neurosci. 41, 13019-13029.

Mak, D. O. D., McBride, S., and Foskett, J. K. (1999). ATP regulation of type 1 inositol 1,4,5-trisphosphate receptor channel gating by allosteric tuning of $\mathrm{Ca}^{2+}$ activation. J. Biol. Chem. 274, 22231-22237.

Mak, D. O. D., McBride, S., and Foskett, J. K. (2001). ATP regulation of recombinant type 3 inositol 1,4,5-trisphosphate receptor channel gating. J. Gen. Physiol. 274, 22231-22237.

Malenka, R. C. (2003). Synaptic plasticity and AMPA receptor trafficking. Ann. N. Y. Acad. Sci. 1003, 1-11.

Mansvelder, H. D., and McGehee, D. S. (2000). Long-term potentiation of excitatory inputs to brain reward areas by nicotine. Neuron 27 , 349-57.

Maricq, A. V., Peterson, A. S., Brake, A. J., Myers, R. M., and Julius, D. (1991). Primary structure and functional expression of the $5 \mathrm{HT} 3$ receptor, a serotonin-gated ion channel. Science 254, 432-443.

Mark, S. O., Ondrias, K., and Marks, A. R. (1998) Coupled gating between individual skeletal muscle $\mathrm{Ca}^{2+}$ release channels (Ryanodine Receptors). Science 281, 818-821.

Mark, S. O., Reiken, S., Hisamatsu, Y., Jayaraman, T., Burkhoff, D., Rosemblit, N., and Marks, A. R. (2000). PKA phosphorylation dissociates FKBP12.6 from the calcium release channel (Ryanodine Receptor): defective regulation in failing hearts. Cell 101, 365-376.

Markram, H., Helm, P. J., and Sakmann, B. (1995). Dendritic calcium transients evoked by single backpropagating action potentials in rat neocortical pyramidal neurons. $J$. Physiol. 485, 1-20.

Marrion, N. V., and Tavalin, S. J. (1998). Selective activation of $\mathrm{Ca}^{2+}$. activated $\mathrm{K}+$ channels by colocalized $\mathrm{Ca}^{2+}$ channels in hippocampal neurons. Nature 395, 900-905.

Matsumoto, M., Nakagawa, T., Inoue, T., Nagata, E., Tanaka, K., Takano, H., Minowa, O., Kuno, J., Sakakibara, S., Yamada, M., Yoneshima, H., Miyawaki, A., Fukuuchi, Y., Furuichi, T., Okano, H., Mikoshiba, K., and Noda, T. (1996). Ataxia and epileptic seizures in mice lacking type 1 inositol 1,4,5-trisphosphate receptor. Nature 379, 168-171.

Matthews, E. A., Linardakis, J. M., and Disterhoft, J. F. (2009). The fast and slow afterhyperpolarizations are differentially modulated in hippocampal neurons by aging and learning. $J$. Neurosci. 29, 4750-4755.

Mattson, M. P. (2004). Pathways towards and away from Alzheimer's disease. Nature 430, 631-639.

Mattson, M. P. (2007). Calcium and neurodegeneration. Aging Cell 6, 337-350.

McEnery, M. W., Dawson, T. M., Verma, A., Gurley, D., Colombini, M., and Snyder, S. H. (1993). Mitochondrial voltage-dependent anion channel. Immunochemical and immunohistochemical characterization in rat brain. J. Biol. Chem. 268, 23289-23296.

McCobb, D. P., and Beam, K. G. (1991) Action potential waveform voltage clamp commands reveal striking differences in calcium entry via low and high voltage-activated calcium channels. Neuron 7, 119-127.

McGraw, C. F., Somlyo, A. V., and Blaustein, M. P. (1980). Localization of calcium in presynaptic nerve terminals. An ultrastructural and electron microprobe analysis. J. Cell Biol. $85,228-241$.

Meissner, G. (1984). Adenine nucleotide stimulation of $\mathrm{Ca}^{2+}$-induced $\mathrm{Ca}^{2+}$. release in sarcoplasmic reticulum. $J$. Biol. Chem. 259, 2365-2374.
Meissner, G. (2002). Regulation of mammalian ryanodine receptors. Front. Biosci. 7, 2072-2080.

Melyan, Z., Wheal, H. V., and Lancaster, B. (2002). Metabotropic-mediated kainite receptor regulation of IsAHP and excitability in pyramidal cells. Neuron 34, 107-114.

Michaelis, M. L., Bigelow, D. J., Schöneich, C., Williams, T. D., Ramonda, L., Yin, D., Hühmer, A. F., Yao, Y., Gao, J., and Squier, T. C. (1996). Decreased plasma membrane calcium transport activity in aging brain. Life Sci. 59, 405-412.

Michaelsen, K., and Lohmann, C. (2010). Calcium dynamics at the developing synapses: mechanisms and functions. Eur. J. Neurosci. 32, 218-223.

Mikoshiba, K. (2007). $\mathrm{IP}_{3}$ Receptor/ $/ \mathrm{Ca}^{2+}$ channel: from discovery to new signaling concepts. J. Neurochem. 102, 1426-1446.

Miller, R. J. (1991). The control of neuronal $\mathrm{Ca}^{2+}$ homeostasis. Prog. Neurobiol. 37, 255-285.

Monyer, H., Sprengel, R., Schoepfer, R., Herb, A., Higuchi, M., Lomeli, H., Burnashev, N., Sakmann, B., and Seeburg, P. H. (1992). Heteromeric NMDA receptors: molecular and functional distinction of subtypes. Science 256, 1217-1221.

Moosmang, S., Haider, N., Klugbauer, N., Adelsberger, H., Langwieser, N., Muller, J., Stiess, M., Marais, E., Schulla, V., Lacinova, L., Goebbels, S., Nave, K. A., Storm, D. R., Hofmann, F., and Kleppisch, T. (2005). Role of hippocampal $\mathrm{Ca}_{\mathrm{v}} 1.2-\mathrm{Ca} 2$ channels in NMDA receptor-independent synaptic plasticity and spatial memory. J. Neurosci. 25, 9883-9892.

Mothet, J. P., Fossier, P., Meunier, F. M., Stinnakre, J., Tauc, L., and Baux, G. (1998). Cyclic ADP-ribose and calcium-induced calcium release regulate neurotransmitter release at a cholinergic synapse of Aplysia $J$. Physiol. 507, 405-414.

Moyer, J. R. Jr., and Disterhoft, J. F. (1994). Nimodipine decreases calcium action potentials in rabbit hippocampal CA1 neurons in an age-dependent and concentrationdependent manner. Hippocampus 4, 11-17.

Mulle, C., Sailer, A., Perez-Otano, I., Dickinson-Anson, H., Castillo, P. E., Bureau, I., Maron, C., Gage, F. H., Mann, J. R., Bettler, B., and Heinemann, S. F. (1998). Altered synaptic physiology and reduced susceptibility to kainite induced seizures in GluR6-deficient mice. Nature 392, 601-605. 
Mulle, C., Sailer, A., Swanson, G. T., Brana, C., O'Gorman, S., Bettler, B., and Heinemann, S. F. (2000) Subunit composition of kainite receptors in hippocampal interneurons. Neuron 28, 475-484.

Murchison, D., and Griffith, W. H. (1999). Age-related alterations in caffeine-sensitive calcium stores and mitochondrial buffering in rat basal forebrain. Cell Calcium 25, 439-452.

Murchison, D., Zawieja, D. C., and Griffith, W. H. (2004). Reduced mitochondrial buffering of voltage-gated calcium influx in aged rat basal forebrain neurons. Cell Calcium 36, 61-75.

Navarro, A. (2004). Mitochondrial enzyme activities as biochemical markers of aging. Mol. Aspects Med. 25, 37-48.

Nayak, S. V., Ronde, P., Spier, A. D., Lummis, S. C., and Nichols, R. A. (1999). Calcium changes induced by presynaptic 5-hydroxytryptamine-3 serotonin receptors on isolated terminals from various regions of the rat brain. Neuroscience 91, 107-117.

Nelson, O., Tu, H., Lei, T., Bentahir, M., de Strooper, B., and Bezprozvanny, I. (2007). Familial Alzheimer diseaselinked mutations specifically disrupt $\mathrm{Ca}^{2+}$ leak function of presenilin 1. J. Clin. Invest. 117, 1230-1239.

Nichols, R. A., and Mollard, P. (1996). Direct observation of serotonin 5 HT3 receptor-induced increases in calcium levels in individual brain nerve terminals. J. Neurochem. 67, 581-592.

Niikura, Y., Abe, K., and Misawa, M. (2004). Involvement of L-type $\mathrm{Ca}^{2+}$ channels in the induction of longterm potentiation in the basolateral amygdala-dentate gyrus pathway of anesthetized rats. Brain Res. 1017, 218-221.

Nishiyama, M., Hong, K., Mikoshiba, K., Poo, M. M., and Kato, K. (2000). Calcium stores regulate the polarity and input specificity of synaptic modification. Nature 408, 584-588.

Nixon, R. A., Saito, K. I., Grynspan, F., Griffin, W. R., Katayama, S., Honda, T., Mohan, P. S., Shea, T. B., and Beermann, M. (1994). Calcium-activated neutral proteinase (calpain) system in aging and Alzheimer's disease. Ann. NY Acad. Sci. 747, 77-91.

Norris, C. M., Blalock, E. M., Chen, K. C., Porter, N. M., and Landfield, P. W. (2002). Calcineurin enhances Ltype $\mathrm{Ca}^{2+}$ channel activity in hippocampal neurons: increased effect with age in culture. Neuroscience 110, 213-225.

Norris, C. M., Korol, D. L., and Foster, T. C. (1996). Increased susceptibility to induction of long-term depression and long-term potentiation reversal during aging. J. Neurosci. 16, 5382-5392.

Obermair, G. J., Szabo, Z., Bourinet, E. and Flucher, B. E. (2004). Differential targeting of the L-type $\mathrm{Ca}^{2+}$ channel alpha $1 \mathrm{C}\left(\mathrm{Ca}_{\mathrm{v}} 1.2\right)$ to synaptic and extrasynaptic compartments in hippocampal neurons. Eur. J. Neurosci. 19, 2109-2122.

Olivera, B. M., Miljanich, G. P., Ramachandran, J., and Adams, M. E. (1994). Calcium channels diversity and neurotransmitter release: The omega-conotoxins and omegaagatoxins. Annu. Rev. Biochem. 63, 823-867.

Oliveria, S. F., Dell'Acqua, M. L., and Sather, W. A. (2007). AKAP79/150 anchoring of calcineurin controls neuronal L-type $\mathrm{Ca}^{2+}$ channel activity and nuclear signaling. Neuron 55 , 261-275.

O’Neill, M. J., Bogaert, L., Hicks, C. A., Bond, A., Ward, M. A., Ebinger, G., Ornstein, P. L., Michotte, Y., and Lodge, D. (2000). LY377770, a novel iGlu5 kainate receptor antagonist with neuroprotective effects in global and focal cerebral ischemia. Neuropharmacology 39, 1575-1588.

O'Neill, M. J., Bond, A., Ornstein, P. L., Ward, M. A., Hicks, C. A., Hoo, K., Bleakman, D., and Lodge, D. (1998). Decahydroisoquinolines: novel competitive AMPA/kainate antagonists with neuroprotective effects in global and focal cerebral ischemia. Neuropharmacology 37, 1211-1222.

Page, K. M., Canti, C., Stephens, G. J., Berrow, N. S., and Dolphin, A. C. (1998). Identification of the amino terminus of neuronal $\mathrm{Ca}^{2+}$ channel $\alpha 1$ subunits $\alpha 1 \mathrm{~B}$ and a1E as an essential determinant of Gprotein modulation. J. Neurosci. 18, 4815-4824.

Palty, R., Silverman, W. F., Hershfinkel, M., Caporale, T., Sensi, S. L., Parnis, J., Nolte, C., Fishman, D., ShoshanBarmatz, V., Herrmann, S., Khananshvili, D., and Sekler, I. (2010). NCLX is an essential component of mitochondrial $\mathrm{Na}+/ \mathrm{Ca}^{2+}$ exchange. Proc. Natl. Acad. Sci. U. S. A. 107, 436-441.

Pankratov, Y., Lalo, U., Krishtal, O. A., and Verkhratsky, A. (2008). P2X receptors and synaptic plasticity. Neuroscience 158, 137-148.

Pankratov, Y., Lalo, U, Krishtal, O. A., and Verkhratsky, A. (2003). P2X receptors excitatory synaptic currents in somatosensory cortex. $\mathrm{Mol}$. Cell. Neurosci. 24, 842-849.
Paoletti, P. (2011). Molecular basis of NMDA receptors functional diversity. Eur. J. Neurosci. 33, 1351-1365.

Park, M. K., Choi, Y. M., Kang, Y. K. and Petersen, O. H. (2008). The endoplasmic reticulum as an integrator of multiple dendritic events. Neuroscientist 14, 68-77.

Patterson, R. L., Boehning, D., and Snyder, S. H. (2004). Inositol 1,4,5trisphosphate receptors as signal integrators. Annu. Rev. Biochem. 73 437-465.

Perkinton, M. S., Sihra, T. S., and Williams, R. J. (1999). $\mathrm{Ca}^{2+}$. permeable AMPA receptors induce phosphorylation of cAMP response element-binding protein through a phosphatidylinositol-3-kinasedependent stimulation of the mitogen-activated protein kinase signaling cascade in neurons. $J$. Neurosci. 19, 5861-5874.

Perocchi, F., Gohil, V. M., Girgis, H. S., Bao, X. R., McCombs, J. E., Palmer, A. E., and Mootha, V. K. (2010). MICU1 encodes a mitochondrial $\mathrm{EF}$ hand protein required for $\mathrm{Ca}^{2+}$ uptake. Nature 467, 291-296.

Pickard, B. S., Malloy, M. P., Christoforou, A., Thomson, P. A., Evans, K. L., Morris, S. W., Hampson, M., Porteous, D. J., Blackwood, D. H., and Muir, W. J. (2006). Cytogenetic and genetic evidence supports a role for the kainate-type glutamate receptor gene, GRIK4, in schizophrenia and bipolar disorder. Mol. Psychiatry 11, 847-857.

Pinheiro, P., and Mulle, C. (2006). Kainate receptors. Cell Tissue Res. 326, 457-482.

Pitts, K. R., Yoon, Y., Krueger, E. W., and McNiven, M. A. (1999). The dynamin-like protein DLP1 is essential for normal distribution and morphology of the endoplasmic reticulum and mitochondria in mammalian cells. Mol. Cell. Biol. 10, 4403-4417.

Pivovarova, N. B., and Andrews, S. B. (2010). Calcium-dependent mitochondrial function and dysfunction in neurons. FEBS J. 277, 3622-3636.

Power, J. M., Wu, W. W., Sametsky, E., Oh, M. M., and Disterhoft, J. F. (2002). Age-related enhancement of the slow outward calcium-activated potassium current in hippocampal CA1 pyramidal neurons in vitro. $J$. Neurosci. 22, 7234-7243.

Pratt, K. G., Zimmerman, E. C., Cook, D. G., and Sullivan, J. M. (2011). Presenilin 1 regulates homeostatic synaptic scaling through Akt signaling. Nat. Neurosci. 14, 1112-1114.

Prins, D., and Michalak, M. (2011). Organellar calcium buffers. Cold
Spring Harb. Perspect. Biol. 3. Pii a004069.

Raymond, C. R., and Redman, S. J. (2002). Different calcium sources are narrowly tuned to the induction of different forms of LTP. $J$. Neurophysiol. 88, 249-255.

Raymond, C. R., and Redman, S. J. (2006). Spatial segregation of neuronal calcium signaling encode different forms of LTP in rat hippocampus. J. Physiol. (Lond.) 570, 97-111.

Redmond, L., and Ghosh, A. (2005). Regulation of dendritic development by calcium signaling. Cell Calcium 37, 411-416.

Retting, J., Sheng, Z. H., Kim, D. K., hodson, C. D., snutch, T. P., and Catterall, W. A. (1996). Isoform-specific interaction of the alphalA subunits of the brain $\mathrm{Ca}^{2+}$ channels with the presynaptic proteins syntaxin and SNAP25. Proc. Natl. Acad. Sci. U. S. A. 93 7363-7368.

Reyes, M., and Stanton, P. K. (1996). Induction of hippocampal longterm depression requires release of $\mathrm{Ca}^{2+}$ from separate presynaptic and postsynaptic intracellular stores. J. Neurosci. 16, 5951-5960.

Ris, L., and Godaux, E. (2007). Synapse specificity of long-term potentiation breaks down with aging. Learn. Mem. 14, 185-189.

Rizzuto, R., Duchen, M. R., and Pozzan, T. (2004). Flirting in little space: the ER/mitochondria $\mathrm{Ca}^{2+}$ liaison. Sci. STKE 2004, rel.

Rizzuto, R., Marchi, S., Bonora, M., Aguiari, P., Bononi, A., De Stefani, D., Giorgi, C., Leo, S., Rimessi, A., Siviero, R., Zecchini, E., and Pinton, P. (2009). $\mathrm{Ca}^{2+}$ transfer from the ER to the mitochondria: when, how, and why. Biochem. Biophys. Acta 1787, 1342-1351.

Rodney, G. G., Williams, B. Y., Strasburg, G. M., Beckingham, K., and Hamilton, S. L. (2000). Regulation of RYR1 activity by $\mathrm{Ca}^{2+}$ and calmodulin. Biochemistry 39, 7807-7812.

Rodríguez-Moreno, A., Herreras, O., and Lerma, J. (1997). Kainate receptors presynaptically downregulate GABAergic inhibition in the rat hippocampus. Neuron 19, 893-901.

Rodríguez-Moreno, A., and Lerma, J. (1998). Kainate receptor modulation of GABA release involves a metabotropic function. Neuron 20, 1211-1218.

Roerig, B., Nelson, D. A., and Katz, L. C. (1997). Fast synaptic signalling by nicotinic acetylcholine and serotonin $5-\mathrm{HT}_{3}$ receptors in developing visual cortex. J. Neurosci. 17, 8353-8362. 
Rogaev, E. I., Sherrington, R., Rogaeva, E. A., Levesque, G., Ikeda, M., Liang, Y., Chi, H., Lin, C., Holman, K., Tsuda, T., Mar, L., Sorbi, S., Nacmias, B., Piacentini, S., Amaducci, L., Chiumakov, I., Cohen, D., Lannfelt, L., Fraser, E., Rommens, J. M., and St George-Hyslop, P. H. (1995). Familial Alzheimer's disease in kindreds with missense mutations in a gene on chromosome 1 related to the Alzheimer's disease type 3 gene. Nature 376, 775-778.

Rose, J., Jin, S. X., and Craig, A. M. (2009). Heterosynaptic molecular dynamics: locally induced propagating synaptic accumulation of CaM kinase II. Neuron 61, 351-358.

Rosenzweig, E. S., and Barnes, C. A. (2003). Impact of aging on hippocampal function: plasticity, network dynamics, and cognition. Prog. Neurobiol. 69, 143-179.

Rozas, J. L., Paternain, A. V., and Lerma, J. (2003). Noncanonical signaling by ionotropic kainate receptors. Neuron 39, 543-553.

Rubinsztein, D. C., Leggo, J., Chiano, M., Norbury, G., Rosser, E., and Craufurd, D. (1997). Genotype at the GluR6 kainate receptor locus are associated with variations in the age of onset of Huntington disease. Proc. Natl. Acad. Sci. U.S.A. 94, 3872-3876.

Ruiz, A., Sachidhanandam, S., Utvik, J. K., Coussen, F., and Mulle, C. (2005). Distinct subunits in heteromeric kainate receptors mediate ionotropic and metabotropic function at hippocampal mossy fiber synapses. J. Neurosci. 25, 11710-11718.

Sandin, M., Jasmin, S., and Levere, T. E. (1990). Aging and cognition: facilitation of recent memory in aged nonhuman primates by nimodipine. Neurobiol. Aging 11, 573-575.

Satoh, T, Ross, C. A., Villa, A, Supattapone, S, Pozzan, T, Snyder, S. H., and Meldolesi, J. (1990). The inositol 1,4,5,-trisphosphate receptor in cerebellar Purkinje cells: quantitative immunogold labeling reveals concentration in an ER subcompartment. J. Cell Biol. 111, 615-624.

Saura, C. A., Choi, S. Y., Beglopoulos, V., Malkani, S., Zhang, D., Shankaranarayana Rao, B. S., Chattarji, S., Kelleher, R. J. 3rd, Kandel, E. R., Duff, K., Kirkwood, A., and Shen, J. (2004). Loss of presenilin function causes impairments of memory and synaptic plasticity followed by agedependent neurodegeneration. $\mathrm{Neu}$ ron 42, 23-36.

Schiffer, H. H., and Heinemann, S. F. (2007). Association of the human kainate receptor GluR7 gene (GRIK3) with recurrent major depressive disorder. Am. J. Med. Genet. B Neuropsychiatr. Genet. 144B, 20-26.

Schmitz, D., Frerking, M., and Nicoll, R. A. (2000). Synaptic activation of presynaptic kainate receptors on hippocampal mossy fiber synapses. Neuron 27, 327-338.

Schmitz, D., Mellor, J., Breustedt, J., and Nicoll, R. A. (2003). Presynaptic kainite receptors impart an associative property to hippocampal mossy fiber long-term potentiation. Nat. Neurosci. 6, 1058-1063.

Schmitz, D., Mellor, J., and Nicoll, R. A. (2001). Presynaptic kainate receptor mediation of frequency facilitation at hippocampal mossy fiber synapses. Science 291, 1972-1976.

Scotty, F., Danik, M., Manseau, F., Lapnate, F., Quirion, R., and Williams, S. (2003). Distinct electrophysiological properties of glutamatergic, cholinergic and GABAergic rat septohippocampal neurons: novel implications for hippocampal rhythmicity. J. Physiol. (Lond.) 551, 927-943.

Shakiryanova, D., Klose, M. K., Zhou, Y., Gu, T., Deitcher, D. L., Atwood, H. L., Hewes, R. S., Levitan, E. S. (2007). Presynaptic ryanodine receptor-activated calmodulin kinase II increases vesicle mobility and potentiates neuropeptide release. J. Neurosci. 27, 7799-7806.

Shankar, S., Teyler, T. J., and Robbins, N. (1998). Aging differentially alters forms of long-term potentiation in rat hippocampal area CA1. J. Neurophysiol. 79, 334-341.

Sharma, G., and Vijayaraghavan, S. (2001), Nicotinic cholinergic signaling in hippocampal astrocytes involves calcium-induced calcium release from intracellular stores. Proc. Natl. Acad. Sci. U.S.A. 98, 4148-4153.

Sharp, A. H., McPherson, P. S., Dawson, T. M., Aoki, C., Campbell, K. P., and Snyder, S. H. (1993). Differential immunohistochemical localization of inositol 1,4,5-trisphosphate- and ryanodine-sensitive $\mathrm{Ca}^{2+}$ release channels in rat brain. J. Neurosci. 13, 3051-3063.

Shen, J. X., and Yakel, J. L. (2009). Nicotinic acetylcholine receptors mediate calcium signaling in the nervous system. Acta Pharmacol. Sin. 30, 673-680.

Sheng, Z.-H., Rettig, J., Cook, T., and Catterall, W. A. (1996). Calciumdependent interaction of N-type calcium channels with the synaptic core-complex. Nature 379, 451-454.
Sheng, Z.-H., Rettig, J., Takahashi, M. and Catterall, W. A. (1994). Identification of a syntaxin-binding site on N-type calcium channels. Neuron 13, 1303-1313.

Sherrington, R., Rogaev, E. I., Liang, Y., Rogaeva, E. A., Levesque, G., Ikeda, M., Chi, H., Lin, C., Li, G., Holman, K., Tsuda, T., Mar, L., Foncin, J. F., Bruni, A. C., Montesi, M. P., Sorbi, S., Rainero, I., Pinessi, L., Nee, L., Chumakov, I., Pollen, D., Brookes, A., Sanseau, P., Polinsky, R. J., Wasco, W., Da Silva, H. A., Haines, J. L., Perkicak-Vance, M. A., Tanzi, R. E., Roses, A. D., Fraser, P. E., Rommens, J. M., and St George-Hyslop, P. H. (1995). Cloning of a gene bearing missense mutations in early-onset familial Alzheimer's disease. Nature 375, 754-760

Shmigol, A., Svichar, N., Kostyuk, P., and Verkhratsky, A. (1996). Gradual caffeine-induced $\mathrm{Ca}^{2+}$ release in mouse dorsal root ganglion neurons is controlled by cytoplasmic and luminal $\mathrm{Ca}^{2+}$. Neuroscience 73 , 1061-1067.

Simmen, T., Aslan, J. E., Blagoveshchenskaya, A. D, Thomas, L., Wan, L., Xiang, Y., Feliciangeli, S. F., Hung, C. H., Crump, C. M. and Thomas, G. (2005). PACS2 controls endoplasmic reticulummitochondria communication and BID-mediated apoptosis. EMBO J. 24, 717-729.

Sitsapesan, R., and Williams, A. J. (1995). The gating of the sheep skeletal sarcoplasmic reticulum Ca2p-release channel is regulated by luminal Ca2p. J. Membr. Biol. 146, 133-144.

Smolders, I., Bortolotto, Z. A., Clarke, V. R., Warre, R., Khan, G. M., O’Neill, M. J., Ornstein, P. L., Bleakman, D., Ogden, A., Weiss, B., Stables, J. P., Ho, K. H., Ebinger, G., Collingridge, G. L., Lodeg, D., and Michotte, Y. (2002). Antagonists of Glu(K5)containing kainate receptors prevent pilocarpine-induced limbic seizures. Nat. Neurosci. 5, 796-804.

Solovyova, N., Veselovsky, N., Toescu, E. C., and Verkhratsky, A. (2002). Ca2+ dynamics in the lumen of the endoplasmic reticulum in sensory neurons: direct visualization of $\mathrm{Ca}^{2+}$. induced $\mathrm{Ca}^{2+}$ release triggered by physiological $\mathrm{Ca}^{2+}$ entry. EMBO J. 21, 622-630.

Sparagna, G. C., Gunter, K. K., Sheu, S. S., and Gunter, T. E. (1995). Mitochondrial calcium uptake from physiological-type pulses of calcium. A description of the rapid uptake mode. J. Biol. Chem. 270, 27510-27515.
Splawski, I., Yoo, D. S., Cherry, A., Clapham, D. E., and Keating, M. T. (2006). CACNA $\mathrm{H}_{1}$ mutations in autism spectrum disorders. J. Biol. Chem. 281, 22085-22091.

Stanley, E. F. (1997). The calcium channel and the organization of the presynaptic transmitter release face. Trends Neurosci. 20, 404-409.

Strutz-Seebohm, N., Korniychuk, G., Schwarz, R., Baltaev, R., Ureche, O. N., Mack, A. F., Ma, Z. L., Hollmann, M., Lang, F., and Seebohm, G. (2006). Functional significance of the kainate receptor GluR6(M836I) mutation that is linked to autism. Cell. Physiol. Biochem. 18, 287-294.

Stutzmann, G. E., Caccamo, A., LaFerla, F. M., and Parker, I. (2004). Dysregulated $\mathrm{IP}_{3}$ signaling in cortical neurons of knock-in mice expressing an Alzheimer's-linked mutation in presenilin 1 results in exaggerated $\mathrm{Ca}^{2+}$ signals and altered membrane excitability. J. Neurosci. 24, 508-513.

Stutzmann, G. E., Smith, I., Caccamo, A., Oddo, S., Laferla, F. M., and Parker, I. (2006). Enhanced ryanodine receptor recruitment contributes to $\mathrm{Ca}^{2+}$ disruptions in young, adult, and aged Alzheimer's disease mice. J. Neurosci. 26, 5180-5189.

Sudhof, T. C. (2004). The synaptic vesicle cycle. Annu. Rev. Neurosci. 27, 509-547.

Sugita, S., Shen, K. Z., and North, R. A. (1992). 5-Hydroxytryptamine is a fast excitatory transmitter at $5-\mathrm{HT}_{3}$ receptors in rat lateral amygdala. Neuron 8, 199-203.

Surprenant, A., and North, R. A. (2009). Signaling at purinergic $\mathrm{P} 2 \mathrm{X}$ receptors. Annu. Rev. Physiol. 71, 333-359.

Sweatt, J. D. (2001). The neuronal MAP kinase cascade: a biochemical signal integration system subserving synaptic plasticity and memory. $J$. Neurochem. 76, 1-10.

Szabadkai, G., Bianchi, K., Várnai, P., De Stefani, D., Wieckowski, M. R. Cavagna, D., Nagy, A. I., Balla, T., and Rizzuto, R. (2006). Chaperonemediated coupling of endoplasmic reticulum and mitochondrial $\mathrm{Ca}^{2+}$ channels. J. Cell Biol. 175, 901-911.

Takei, K., Shin, R. M., Inoue, T., Kato, K., and Mikoshiba, K. (1998). Regulation of nerve growth mediated by inositol 1,4,5-trisphosphate receptors in growth cones. Science 282, 1705-1708.

Talley, E. M., Cribbs, L. L., Lee, J. H., Daud, A., Perez-Reyes, E., and Volsen, S. G. (1999). Differential distribution of the voltage-dependent calcium channels $\alpha_{1 \mathrm{G}}$ subunit mRNA and protein throughout the 
mature rat brain. Eur. J. Neurosci. 11, 2949-2964.

Tanaka, D., Nakada, K., Takao, K., Ogasawara, E., Kasahara, A., Sato, A., Yonekawa, H., Miyakawa, T., and Hayashi, J. (2008). Normal mitochondrial respiratory function is essential for spatial remote memory in mice. Mol. Brain 16, 1-21.

Tang, Y., and Zucker, R. S. (1997). Mitochondrial involvement in posttetanic potentiation of synaptic transmission. Neuron 18, 483-491.

Taylor, C. W., da Fonseca, P. C. A., and Morris, E. P. (2004). $\mathrm{IP}_{3}$ receptors: the search for structure. Trends Biochem. Sci. 29, 210-219.

Taylor, C. W., Rahman, T., and Pantazaka, E. (2009). Targeting and clustering of $\mathrm{IP}_{3}$ receptors: Key determinants of spatially organized $\mathrm{Ca}^{2+}$ signals. Chaos 19, 037102.

Tecott, L. H., Maricq, A. V., and Julius, D. (1993). Nervous system distribution of the 5-HT3 receptor in rat brain using radioligand binding. Proc. Natl. Acad. Sci. U.S.A. 90, 1430-1443.

Thibault, O., Hadley, R., and Landfield, P. W. (2001). Elevated postsynaptic $\left[\mathrm{Ca}^{2+}\right] \mathrm{i}$ and L-type calcium channel activity in aged hippocampal neurons: relationship to impaired synaptic plasticity. J. Neurosci. 21, 9744-9756.

Thibault, O., and Landfield, P. W. (1996). Increase in single L-type calcium channels in hippocampal neurons during aging. Science 272, 1017-1020.

Thompson, A. J., and Lummis, S. C. (2007). The 5-HT3 receptor as a therapeutic target. Expert Opin. Ther. Targets 11, 527-540.

Tian, X., and Feig, L. A. (2006). Agedependent participation of RasGRF proteins in coupling calciumpermeable AMPA glutamate receptors to Ras/Erk signaling in cortical neurons. J. Biol. Chem. 28, 7578-7582.

Toescu, E. C., Verkhratsky, A., and Landfield, P. W. (2004). $\mathrm{Ca}^{2+}$ regulation and gene expression in normal brain aging. Trends Neurosci. 27, 614-620.

Toescu, E. C., and Vreugdenhil, M. (2010). Calcium and normal brain ageing. Cell Calcium 47, 158-164.

Tollefson, G. D. (1990). Short-term effects of the calcium channel blocker nimodipine (Bay-e-9736) in the management of primary degenerative dementia. Biol. Psychiatry 27, 1133-1142.

Tonkikh, A., Janus, C., El-Beheiry, H., Pennefather, P. S., Samoilova, M., McDonald, P., Ouanounou, A., and
Carlen, P. L. (2006). Calcium chelation improves spatial learning and synaptic plasticity in aged rats. Exp. Neurol. 197, 291-300.

Tonkikh, A. A., and Carlen, P. L. (2009). Impaired presynaptic cytosolic and mitochondrial calcium dynamics in aged compared to young adult hippocampal CA1 synapses ameliorated by calcium chelation. Neuroscience 159, 1300-1308.

Traynelis, S. F., Wollmuth, L. P., McBain, C. J., Menniti, S. F., Vance, K. M., Ogden, K. K., Hansen, K. B., Yuan, B., Myers, S. J., and Dingledine, R. (2010). Glutamate receptor ion channels: structure, regulation, and function. Pharmacol. Rev. 62, 405-496.

Tripathy, A., and Meissner, G. (1996). Sarcoplasmic reticulum lumenal $\mathrm{Ca}^{2+}$ has access to cytosolic activation and inactivation sites of skeletal muscle $\mathrm{Ca}^{2+}$ release channel. Biophys. J. 70, 2600-2615.

Tripathy, A., Xu, L., Mann, G., and Meissner, G. (1995). Calmodulin activation and inhibition of skeletal muscle Ca2prelease channel (ryanodine receptor). Biophys. J. 69, 106-119.

Tsang, C. W., Elrick, D. B., and Charlton, M. P. (2000). alpha-Latrotoxin releases calcium in frog motor nerve terminals. J. Neurosci. 20, 8685-8692.

Tsien, R. W., Lipscombe, D. V., Madison, D. V., Bley, K. R., and Fox, A. P. (1988). Multiple types of neuronal calcium channels and their selective modulation. Trends Neurosci. 11, 431-438.

Tu, H., Nelson, O., Bezprozvanny, A., Wang, Z., Lee, S. F., Hao, Y. H., Serneels, L., De Strooper, B., Yu, G., and Bezprozvanny, I. (2006). Presenilins form $\mathrm{ER} \mathrm{Ca}^{2+}$ leak channels, a function disrupted by familial Alzheimer's disease-linked mutations. Cell 126, 981-993.

Tu, J. C., Xiao, B., Yuan, J. P., Lanahan, A. A., Leoffert, K., Li, M., Linden, D. J., and Worley, P. F. (1998). Homer binds a novel proline-rich motif and links group 1 metabotropic glutamate receptors with $\mathrm{IP}_{3}$ receptors. Neuron 21, 717-726.

van Hooft, J. A., and Vijverberg, H. P. M. (2000). 5- $-\mathrm{HT}_{3}$ receptors and neurotransmitter release in the CNS: a nerve ending story? Trends Neurosci. 23, 605-610.

Vandecaetsbeek, I., Vangheluwe, P., Raeymaekers, L., Wuytack, F., and Vanoevelen, J. (2011). The $\mathrm{Ca}^{2+}$ pimps of the endoplasmic reticulum and Golgi apparatum. Cold Spring Harb. Perspect. Biol. 3. Pii a004184.
Vasington, F., and Murphy, J. V. (1962). $\mathrm{Ca}^{2+}$ uptake by rat kidney mitochondria and its dependence on respiration and phosphorylation. $J$. Biol. Chem. 237, 2670-2677.

Verkhratsky, A. (2005). Physiology and pathophysiology of the calcium store in the endoplasmic reticulum of neurons. Physiol. Rev. 85, 201-279.

Verstreken, P., Ly, C. V., Venken, K. J., Koh, T. W., Zhou, Y., and Bellen, H. J. (2005). Synaptic mitochondria are critical form mobilization of reserve pool vesicles at Drosophila neuromuscular junctions. Neuron 47, 365-378.

Vignes, M., and Collingridge, G. (1997). The synaptic activation of kainate receptors. Nature 388, 179-182.

Vissel, B., Royle, G. A., Christie, B. R., Schiffer, H. H., Ghetti, A., Tritto, T., Perez-Otano, I., Radcliffe, R. A., Seamans, J., Sejnoski, T., Wehner, J. M., Collins, A. C., O'Gorman, S., and Heinemann, S. F. (2001). The role of RNA editing of kainate receptors in synaptic plasticity and seizures. Neuron 29, 217-227.

Wallace, T. L., and Porter, R. H. (2011). Targeting the nicotinic alpha7 acetyltcholine receptor to enhance cognition in disease. Biochem. Pharmacol. 82, 891-903.

Wang, H. J., Guay, G., Pogan, L., Sauvé, R., and Nabi, I. R. (2000). Calcium regulates the association between mitochondria and smooth subdomain of the endoplasmic reticulum. J. Cell Biol. 150, 1489-1498.

Weeber, E. J., Levy, M., Sampson, M. J., Anflous, K., Armstrong, D. L., Brown, S. E., Sweatt, J. D., and Craigen, W. J. (2002). The role of mitochondrial porins and the permeability transition pore in learning and synaptic plasticity. J. Biol. Chem. 277, 18891-18897.

Westenbroek, R. E., Hell, J. W., Warner C., Dubel, S. J., Snutch, T. P., and Cattarell, W. (1992). Biochemical properties and subcellular distribution of an N-type calcium channels $\alpha 1$ subunit. Neuron 6, 1099-1115.

Wilson, G. M., Flibotte, S., Chopra, V., Melnyk, B. L., Honer, W. G., and Holt, R. A. (2006). DNA copynumber analysis in bipolar disorder and schizophrenia reveals aberrations in genes involved in glutamate signaling. Hum. Mol. Genet. 15 , 743-749.

Wiser, O., Tobi, D., Trus, M., and Atlas, D. (1997) Synaptotagmin restores kinetic properties of a syntaxinassociated N-type voltage sensitive calcium channel. FEBS Lett. 404 203-207.
Wisgirda, M. E., and Dryer, S. E. (1994). Functional dependence of $\mathrm{Ca}^{2+}$-activated $\mathrm{K}+$ current on $\mathrm{L}$ and $\mathrm{N}$-type $\mathrm{Ca}^{2+}$ channels: differences between chicken sympathetic and parasympathetic neurons suggest different regulatory mechanisms. Proc. Natl. Acad. Sci. U.S.A. 91, 2858-2862.

Wo, Z. G., and Oswald, R. E. (1994). Transmembrane topology of two kainite receptor subunits revealed by N-glycosylation. Proc. Natl. Acad. Sci. U.S.A. 91, 7154-7158.

Wu, G. Y., Deisseroth, K., and Tsien, R. W. (2001). Activity-dependent CREB phosphorylation: convergence of a fast, sensitive calmodulin kinase pathway and a slow, less sensitive mitogen-activated protein kinase pathway. Proc. Natl. Acad. Sci. U.S.A. 98, 2808-2813.

Wu, L. G., Westenbroek, R. E., Borst, J. G., Catterall, W. A., and Sakmann, B. (1999). Calcium channels types with distinct presynaptic localization couple differentially to transmitter release in single calyx-type synapses. J. Neurosci. 19, 726-736.

Wu, L. G., Borst, J. G. G., and Sakmann, B. (1998). R-type $\mathrm{Ca}^{2+}$ currents evoke transmitter release at a rat central synapses. Proc. Natl. Acad. Sci. U.S.A. 95, 4720-4725.

Xiong, J., Verkhratsky, A., and Toescu, E. C. (2002). Changes in mitochondrial status associated with altered $\mathrm{Ca}^{2+}$ homeostasis in aged cerebellar granule neurons in brain slices. $J$. Neurosci. 22, 10761-10771.

Yakel, J. L. (2000). “The 5-HT3 receptor channel: function, activation and regulation," in Pharmacology of Ionic Channel Function: Activators and Inhibitors, ed. M. Endo (Berlin: Springer-Verlag), 541-560.

Yakel, J. L., Shao, X. M., and Jackson, M. B. (1990). The selectivity of the channel coupled to the 5-HT3 receptor. Brain Res. 533, 46-52.

Yamaguchi, N., Xu, L., Pasek, D. A., Evans, K. E., Chen, S. R. W., and Meissner, G. (2005). Calmodulin regulation and identification of calmodulin binding region of Type-3 ryanodine receptor calcium release channel. Biochemistry 44, 15074-15081.

Yang, F., He, X. P., Russell, J., and Lu, B. (2003). $\mathrm{Ca}^{2+}$ influx-independent synaptic potentiation mediated by mitochondrial $\mathrm{Na}+/ \mathrm{Ca}^{2+}$ exchanger and protein kinase C. J. Cell Biol. 163, 511-523.

Yang, J. (1990). Ion permeation through 5-hydroxytryptaminegated channels in neuroblastoma 
N18 cells. J. Gen. Physiol. 96, 11771198.

Yokoyama, C. T., Myers, S. J., Fu, J., Mockus, S. M, Scheuer, T., and Catterall, W. A. (2005). Mechanism of SNARE protein binding and regulation of $\mathrm{Ca}_{\mathrm{v}} 2$ channels by phosphorylation of the synaptic protein interaction site. Mol. Cell. Neurosci. 28, 1-17.

Yokoyama, C. T., Westenbroek, R. E., Hell, J. W., Soong, T. W., Snutch, T. P., and Catterall, W. A. (1995). Biochemical properties and subcellular distribution of the neuronal class $\mathrm{E}$ calcium channel alpha 1 subunit. J. Neurosci. 15, 64196432.

Yu, D. F., Wu, P. F., Fu, H., Cheng, J., Yang, Y. J., Chen, T., Long, L. H., Chen, J. G., and Wang, F. (2011). Aging-related alterations in the expression and distribution of GluR2 and PICK1 in the rat hippocampus. Neurosci. Lett. 497, 42-45.

Zaidi, A., Barron, L., Sharov, V. S., Schöneich, C., Michaelis, E. K., and Michaelis, M. L. (2003). Oxidative inactivation of purified plasma membrane $\mathrm{Ca}^{2+}$-ATPase by hydrogen peroxide and protection by calmodulin. Biochemistry 42, 12001-12010.

Zamponi, G. W., Bourinet, E., Nelson, D., Nargeot, J., and Snutch, T. P. (1997). Crosstalk between G proteins and protein kinase $\mathrm{C}$ mediated by the calcium channel $\alpha 1$ subunit. Nature 385, 442-446.

Zamponi, G. W., Lory, P., and Perez-Reyes, E. (2010). Role of voltage-gated calcium channels in epilepsy. Eur. J. Physiol. 460, 395-403.

Zhang, C., Wu, B., Beglopoulos, V., Wines-Samuelson, M., Zhang, D., Dragatsi, I., Sudhof, T. C., and Shen, J. (2009). Presenilins are essential for regulating neurotransmitter release. Nature 460, 632-636.

Zhang, D., Zhang, C., Ho, A., Kirkwood, A., Sudhof, T. C., and Shen, J. (2010). Inactivation of presenilins causes pre-synaptic impairment prior to post-synaptic dysfunction. J. Neurochem. 115, 1215-1221.

Conflict of Interest Statement: The authors declare that the research was conducted in the absence of any commercial or financial relationships that could be construed as a potential conflict of interest.
Received: 17 January 2012; paperpending published: 12 February 2012; accepted: 26 March 2012; published online: 13 April 2012.

Citation: Kawamoto EM, Vivar $C$ and Camandola S (2012) Physiology and pathology of calcium signaling in the brain. Front. Pharmacol. 3:61. doi: 10.3389/fphar.2012.00061

This article was submitted to Frontiers in Neuropharmacology, a specialty of Frontiers in Pharmacology.

Copyright (C) 2012 Kawamoto, Vivar and Camandola. This is an openaccess article distributed under the terms of the Creative Commons Attribution Non Commercial License, which permits non-commercial use, distribution, and reproduction in other forums, provided the original authors and source are credited. 